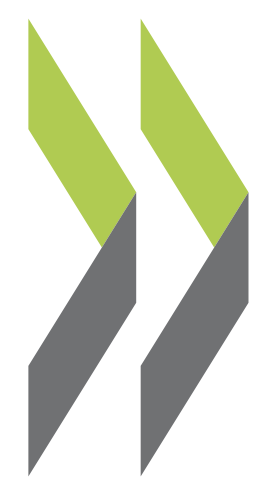

OECD Social, Employment and Migration Working Papers No. 240

Treating all children equally? Why policies should adapt to evolving family living Antonela Miho, arrangements

\title{
Olivier Thévenon
}


DELSA/ELSA/WD/SEM(2020)5

For Official Use

English - Or. English

10 March 2020

DIRECTORATE FOR EMPLOYMENT, LABOUR AND SOCIAL AFFAIRS

EMPLOYMENT, LABOUR AND SOCIAL AFFAIRS COMMITTEE

Treating all children equally?

Why policies should adapt to evolving family living arrangements

Antonela Miho, Paris School of Economics, Antonela.MIHO@psemail.eu

Olivier Thévenon, OECD, Olivier.THEVENON@oecd.org

JT03458634 
Table of Contents

OECD Social, Employment and Migration Working Papers.......................................................... 4

Acknowledgements ............................................................................................................................................ 5

1. Introduction ............................................................................................................................................. 7

2. Changes in family living arrangements: how are children impacted? .....................................9

2.1. The share of children with non-married parents increases ....................................................... 9

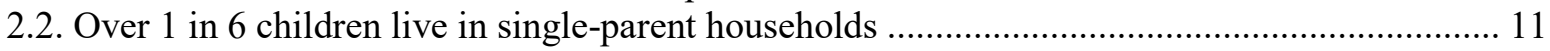

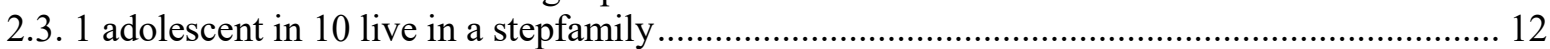

2.4. Increased complexity and fluidity of family living arrangements ........................................... 13

2.5. Single-parent families are more likely to experience poverty .................................................... 14

3. Supporting all children with equal rights ........................................................................................... 19

3.1. Registered partnership as an alternative to marriage and informal cohabitation ........................ 20

3.2. Make tax and benefit eligibility rules more neutral vis-à-vis parental marital status. ............... 22

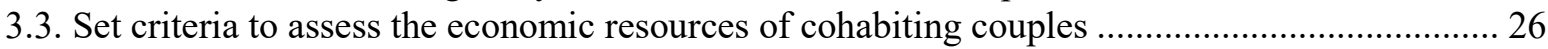

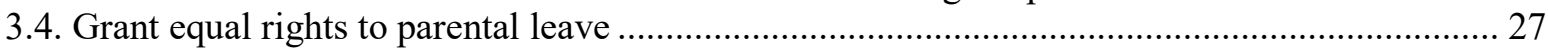

3.5. Strengthen protection in the event of the death of an unmarried parent .................................... 28

3.6. Adapt child maintenance support to modern family living arrangements ................................. 31

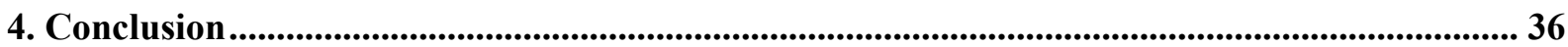

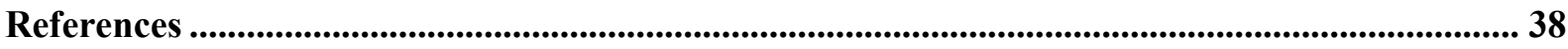

\section{Tables}

Table 1. Recognition of registered partnerships and cohabitation

\section{Figures}

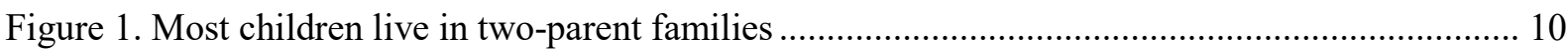

Figure 2. Increasing proportion of children with two cohabiting parents ......................................... 10

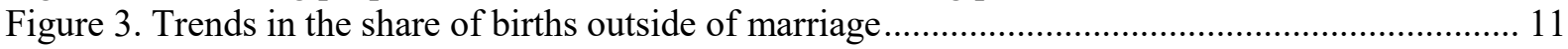

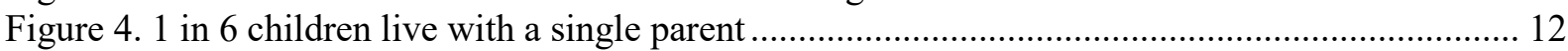

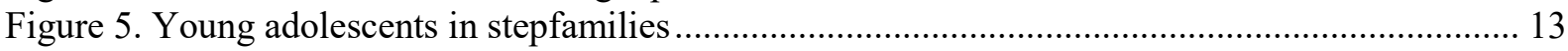

Figure 6. Young adolescents commuting between the two homes of their separated parents .............. 14

Figure 7. Single-parent families are on average three times more likely to be poor than two-parent families.

Figure 8. Tax treatment and eligibility to social assistance by legal family form, 2016 ….................. 23

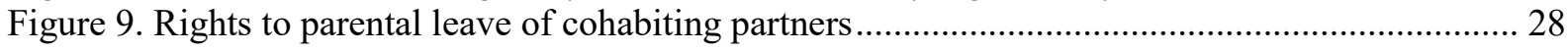

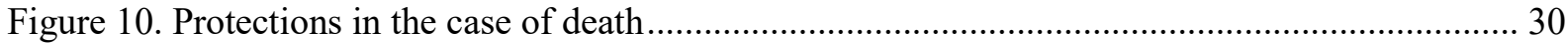

Figure 11. In case partners split up, do statutory rules on alimony to former partners apply?............. 32 


\section{Boxes}

Box 1. Children's family living arrangements: household categorisations and their limits................ 16

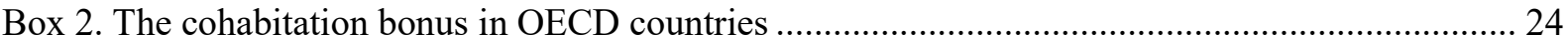




\title{
OECD Social, Employment and Migration Working Papers
}

\author{
www.oecd.org/els/workingpapers
}

OECD Working Papers should not be reported as representing the official views of the OECD or of its member countries. The opinions expressed and arguments employed are those of the author(s).

Working Papers describe preliminary results or research in progress by the author(s) and are published to stimulate discussion on a broad range of issues on which the OECD works. Comments on Working Papers are welcomed, and may be sent to els.contact@oecd.org.

This series is designed to make available to a wider readership selected labour market, social policy and migration studies prepared for use within the OECD. Authorship is usually collective, but principal writers are named. The papers are generally available only in their original language - English or French - with a summary in the other.

This document and any map included herein are without prejudice to the status of or sovereignty over any territory, to the delimitation of international frontiers and boundaries and to the name of any territory, city or area.

\section{Note on Israeli Statistical data}

The statistical data for Israel are supplied by and under the responsibility of the relevant Israeli authorities. The use of such data by the OECD is without prejudice to the status of the Golan Heights, East Jerusalem and Israeli settlements in the West Bank under the terms of international law.

(C) OECD 2020

\footnotetext{
You can copy, download or print OECD content for your own use, and you can include excerpts from OECD publications, databases and multimedia products in your own documents, presentations, blogs, websites and teaching materials, provided that suitable acknowledgment of OECD as source and copyright owner is given. All requests for commercial use and translation rights should be submitted to rights@,oecd.org.
} 


\section{Acknowledgements}

The OECD Directorate for Employment, Labour, and Social Affairs (ELS) prepared this report under the senior leadership of Stefano Scarpetta (Director of ELS), Mark Pearson (Deputy Director of ELS), Monika Queisser (Senior Counsellor, Head of the OECD Social Policy Division and leader of the OECD Horizontal Project on Gender Equality), and Willem Adema (Senior Economist). Willem Adema and Tracey Burns from the OECD Directorate for Education \& Skills are also acknowledged for their valuable comments on earlier drafts.

The financial support provided by the Caisse Nationale d'Allocations Familiales in France (www.caf.fr) for this report is gratefully acknowledged. 


\begin{abstract}
Modern family life brings with it profound changes to children's family living arrangements. An increasing number of children live with unmarried parents whose informal cohabitation implies unequal rights in terms of access to welfare benefit and social protection programmes compared to those in married life. In addition, children experiencing family dissolution are increasingly likely to share their time between the two homes of the separated parents, and/or to live in a stepfamily. The family living arrangements that result from these trends are very diverse and generally not well identified by official statistics, as well as their consequences on families' living standards.

This paper takes stock of the trends in children's family living arrangements based on available international statistics and calls for the development of data that more accurately and reliably reflect children's family situation and its economic consequences. It also discusses adaptations of social protection systems to ensure that all children receive support appropriate to their concrete family living arrangements, and to guarantee that children in a non-traditional family setting are treated on an equal footing vis-à-vis children with married parents.
\end{abstract}

The paper particularly discusses issues raised by the fact that children whose parents live together informally do not always have the same legal and economic security as children of married couples. It also reviews challenges associated with the fact that parents are increasingly sharing custody of their children after separation.

Key words: family complexity; family fluidity; cohabitation; registered partnership; family policy

\title{
Résumé
}

La vie familiale moderne entraîne de profonds changements dans les conditions de vie des enfants. Un nombre croissant d'enfants vivent avec des parents non mariés dont la cohabitation informelle implique des droits inégaux en termes d'accès à la protection sociale par rapport à ceux de la vie maritale. En outre, les enfants en situation de dissolution familiale sont de plus en plus susceptibles de partager leur temps entre les deux foyers des parents séparés, et/ou de vivre dans une famille recomposée. Les modes de vie familiaux qui résultent de ces tendances sont très divers et généralement mal identifiés par les statistiques officielles, de même que leurs conséquences sur le niveau de vie des familles.

Le présent document fait le point sur les tendances des conditions de vie des familles d'enfants sur la base des statistiques internationales disponibles et appelle à l'élaboration de données qui reflètent de manière plus précise et plus fiable la situation familiale des enfants et ses conséquences économiques. Il examine également les adaptations des systèmes de protection sociale pour garantir que tous les enfants reçoivent un soutien adapté à leurs conditions de vie familiales concrètes et que les enfants vivant dans un cadre familial non traditionnel soient traités sur un pied d'égalité avec les enfants dont les parents sont mariés.

Le document aborde en particulier les questions soulevées par le fait que les enfants dont les parents vivent ensemble de manière informelle n'ont pas toujours la même sécurité juridique et économique que les enfants de couples mariés. Il examine également les défis liés au fait que les parents partagent de plus en plus la garde de leurs enfants après la séparation.

Mots clés : complexité de la famille ; fluidité de la famille ; cohabitation ; politique familiale 


\section{Introduction}

1. In the 1970s, the vast majority of families consisted of two married parents, and only about five percent of households were headed by a single parent (Sorrentino, $1990_{[1]}$ ) (Pryor, 2013 ${ }_{[2]}$ ) - usually the mother. By 2018, among OECD countries with available data, only 66 percent of children lived with two married parents, while 15.3 percent lived with two cohabitating parents and 17.2 percent lived with a single parent (OECD Family Database, 2019). Some of this shift is due to changes in partnering behaviour, increasing fluidity of partnerships and changing fertility patterns contributing to increases in nonmarital births and multiple-partner fertility (Abela and Walker, 2013 [3]; Berger and Carlson, $2020_{[4]}$; Pailhé et al., 2014[5]).

2. As a result of these changes, children's experiences of family life are increasingly diverse. A growing number of children are born or grow up with parents who cohabit informally, with rights to benefits and social protection that in many jurisdictions are different from those for children with married parents. In addition, family reconstitution after family break-up is becoming more frequent, and patterns of family reconstitution today are more heterogeneous than they were only a few years ago.

3. Children can live with one biological parent and with a "step-parent" (if their resident biological parent is married or in a registered partnership) or a "social parent" (if the parent is cohabiting informally), and/or may commute between the home of their two biological parents. They may have siblings, half-siblings, step-siblings, and/or "social siblings", and they may live with some or all of these siblings some or all of the time.

4. Furthermore, if one of the parents leaves home, another parental partner may enter the household or there could be a change in the child custody agreements among parents, creating "fluidity" in family living arrangements during childhood. Therefore, it is important for policy to ensure that children are adequately protected against changes in family living arrangements that can affect various aspects of their economic situation and other aspects of well-being.

5. In response to these changes in family life, family policies and social protection systems have somewhat adapted to take into account, in particular, the new "risk" associated with the increase in the number of divorces. For example, many countries have introduced and strengthened support for single-parent families. Some adaptations also address parental obligations in case of separation and divorce and/or have extended access to social and/or fiscal benefits to families with unmarried parents.

6. However, these reforms remain limited in light of the rise of informal cohabitation and the diversity and complexity of certain family living arrangements. This diversity creates inequities across children given large variation in the degree of social protection and assistance provided to families with children often based on the family's legal status. In many countries, children with informally cohabiting parents do not have the same access to benefits as children with married parents. Similarly, financial support for children affected by informal partnership break-up or death of a parent is often not the same as when parents were previously married. 
7. Furthermore, changes in family behaviours and their consequences are not uniform across socio-economic and demographic groups, adding more complexity to the adaption of family policies to the diversification of families. These differences may lead children to experience very different family lives depending on the parents' level of education and income, and these differences may impact children's standard of living, as well as their educational achievements and later outcomes in life (McLanahan and Jacobsen, 2015 [6]). On the one hand, parental separation and divorce and childbearing outside marriage are concentrated among poor and working class parents and this is worrisome in that these families are already financially struggling. By contrast, educated parents invest more time and money in child care and education (Doepke and Zilibotti, 2019 ${ }_{[7]}$ ), and they tend to marry more frequently than lower educated parents, often giving children greater protection against parental separation and death than if the parents are unmarried. When they separate, highly educated parents have more opportunities to share the custody of children and to maintain a decent level of income for their children. For all social categories, family life patterns have diversified, and children may experience a succession of life episodes with different family living arrangements depending on the parents' decisions to marry or not, to separate and/or enter a new union in which they will or will not have additional children.

8. Growing family complexity and diversity has increased uncertainty about family relationships and weakens the private safety net provided by families for their members (Seltzer, $2019_{[8]}$ ). In order to respond to such uncertainty, it is necessary that the legal obligations of family members and that the rules providing access to public benefits and safety nets are adapted to the diversity of family living arrangements.

9. This paper reviews trends regarding children's family living arrangements and highlights challenges raised by the increasing informality and complexity of family living arrangements in ensuring that all children have equal access to the same level of social support. It also discusses policy developments that can be adopted to ensure that parents of children in non-traditional family settings get access to social protections that fully suit their family living arrangements.

10. The paper focuses on issues affecting families with opposite-sex parents, because the case of same-sex parents involves ethical, legal and cultural issues that are specific and deserve special analysis beyond the scope of the present discussion. Similarly, families with parents of different nationalities or migrant families also have characteristics that add to the diversity of family situations, beyond the present discussion. 


\section{Changes in family living arrangements: how are children impacted?}

\subsection{The share of children with non-married parents increases}

11. Across the OECD, over 8 in 10 children live in households with two parents, but rates vary from less than 7 in 10 children in Latvia and the United States to 9 in 10 in Turkey and Greece (Figure 1). In contrast, the proportion of children living with two unmarried parents is increasing across the OECD: almost 1 in 6 children today live with non-married parents, while on average, this situation applied to 1 in 10 children in 2007 (Figure 2) ${ }^{1}$. The increase results from declining marriage rates and the growing acceptance of cohabitation as a way to establish a stable relationship (Perelli-Harris et al., $2014_{[9]}$ ).

12. Cross-country disparities in the proportion of children with cohabitating parents are quite large. The share of children living with two cohabiting parents is, for instance, as high as 3 out of 10 children in Estonia, to almost none in Greece, where almost all children live with married parents. Trends also differ across the OECD, with an increase of over 10 percentage points in the proportion of children with cohabiting parents since 2005 in Belgium, Estonia and Poland, in contrast to a slight decrease in only four countries Denmark, Greece, Iceland and Sweden.

\footnotetext{
${ }^{1}$ Also, a small proportion of children - but up to 3-4\% in in Denmark or the United States - do not live with any parent, but do live in a private household (i.e., not in "collective" households). These children may live with their grand-parents, with other family members or in foster care. However, it is difficult to comment further on the specifics of the living situation of these children due to the lack of available data.
} 
Figure 1. Most children live in two-parent families

Distribution (\%) of children (aged 0-17a) by presence and marital status of parents in the household ${ }^{\mathrm{b}}, 2018^{\mathrm{c}}$ ■Living with two parents (unspecified) $(\searrow) \square$ Two married parents $\square$ Two cohabiting parents $\square$ Living with a single parent $\square$ Other

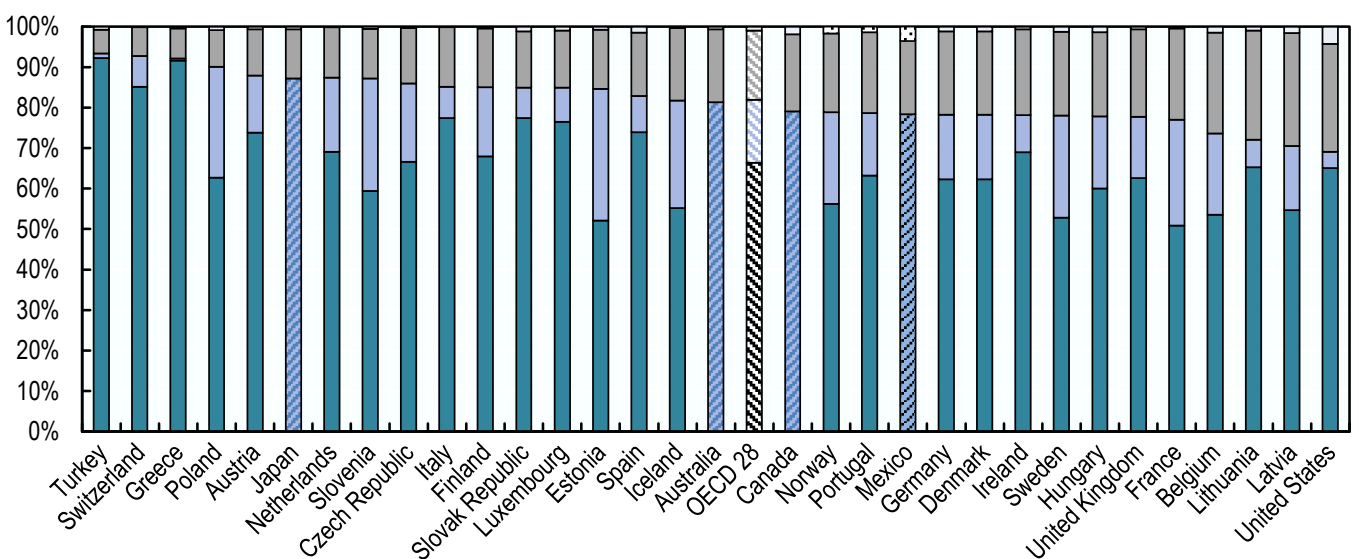

Notes: a) For Japan and Mexico, children aged 0-14; b) 'Parents' generally refers to both biological parents and step-, adoptive parents. 'Living with two married parents' refers to situations where a child lives in a household with two adults that are considered parents and these parents are married to each other or have a registered partnership. 'Living with two cohabiting parents' refers to situations where a child lives in a household with two adults who are considered parents and who are cohabiting without being married nor registered. 'Living with a single parent' refers to situations where a child lives in a household with only one adult who is considered a parent. 'Other' refers to a situation where the child lives without any parent; c) Data for Mexico refer to 2010, for Australia to 2012, for Japan to 2015, for Canada and Iceland to 2016, and for France, Hungary, Ireland, Luxembourg, Turkey, Slovak Republic, and Switzerland refer to 2017.

Source: OECD Family Database, SF1.2 Children in families.

Figure 2. Increasing proportion of children with two cohabiting parents

Proportion of children (aged 0-17) living with two cohabiting parents.

$\square 2018 \bigcirc 2007$

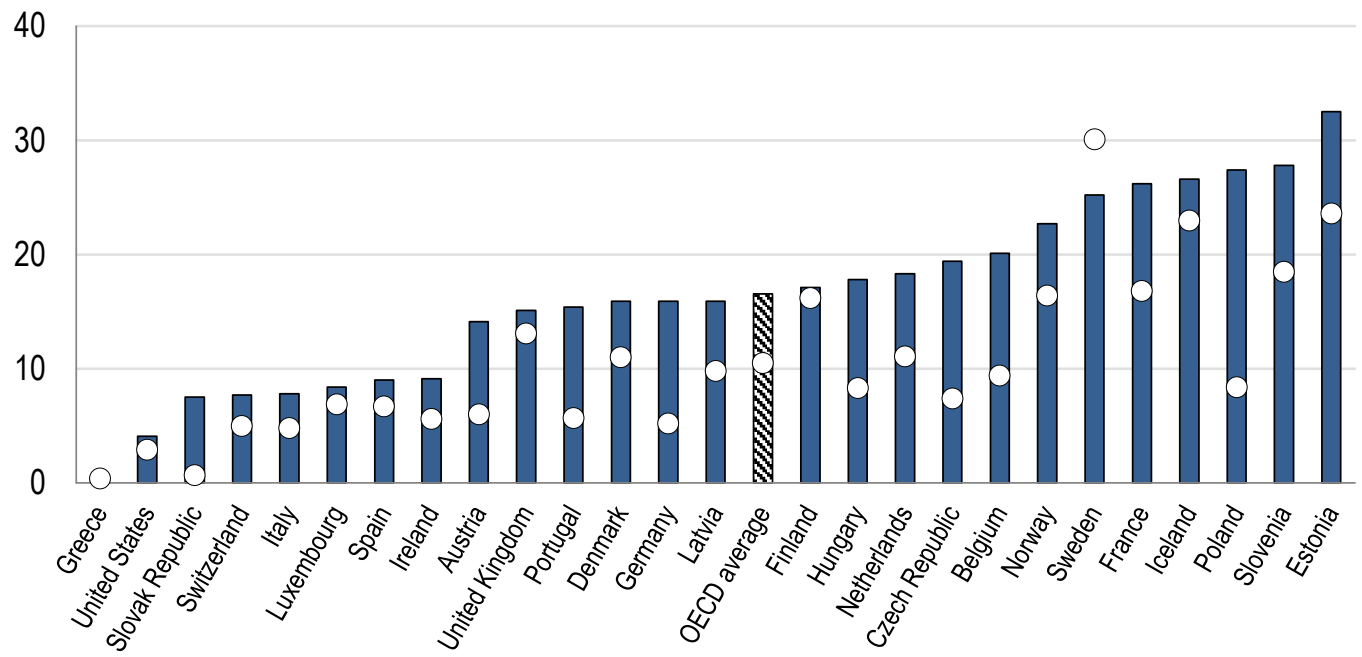

Note: Data for France, Germany, Iceland, Ireland, Luxemburg, Norway, Portugal, Slovak Republic, Switzerland, and the United Kingdom refer to 2016.

Source: OECD Family Database, SF1.2 Children in families. 
13. At the same time, the proportion of children born outside of marriage has increased in almost all OECD countries (Figure 3). In 1970 in most OECD countries, less than 10\% of children were born outside of marriage, with the average rate across OECD countries with available data at just $7.2 \%$. This OECD average grew to just over $24 \%$ by 1995 and, by 2017 , to almost as high as $40 \%$. Increases are particularly large in Belgium, Norway, and Slovenia, where the proportion of children born outside of marriage has increased by almost 50 percentage points since 1970 . This increase could be due to a growing acceptance to have a child out of wedlock, to couples delaying marriage even if they have a child, or to couples choosing to forgo marriage in lieu of other less-traditional family forms, such as cohabitation.

Figure 3. Trends in the share of births outside of marriage

Proportion (\%) of all births where the mother's marital status at the time of birth is other than married, 1970, 1990 and 2017 or latest available year

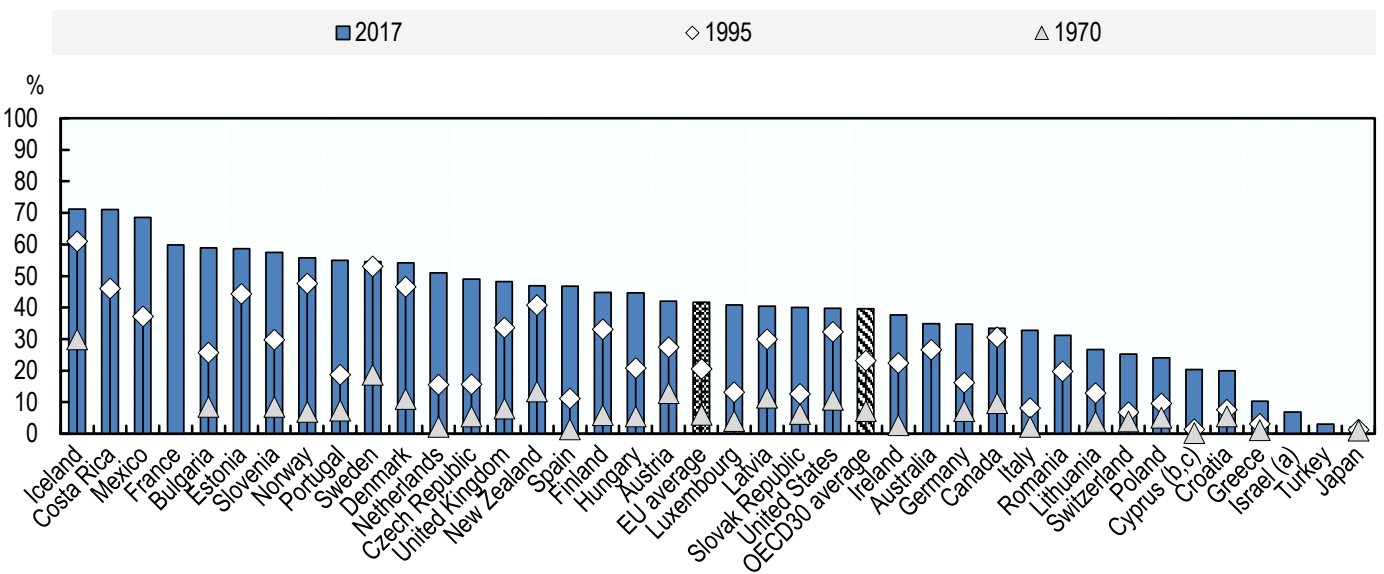

Note: Data for Australia, Canada (1970 only), Japan, Korea and New Zealand refer to ex-nuptial/out-ofwedlock births, that is, where the child's parents are not registered as married to each other (or, for New Zealand only, in a civil union with each other) at the time of the birth. For all other countries, data refer to births to mothers where the mother's marital status at the time of birth was other than married. For Canada, births to mothers whose marital status is other than married as a proportion of births where the mother's marital status is recorded. In 2017, the mother's marital status was not recorded on 8\% of births. For Mexico, births to mothers whose civil status is other than married as a proportion of births where the mother's civil status is recorded. In 2017, the mother's civil status was not recorded on $8 \%$ of births. For Israel, data refer to births to unmarried Jewish women as a proportion of all births to Jewish women, only. For the United States, data for 1970 are based on estimates. $(a, b, c)$ See notes to Chart SF2.4.A.

Source: for European countries, Eurostat Demographic Statistics; for Australia, Australian Bureau of Statistics, for Canada, Statistics Canada, for Chile, INE, for Costa Rica, INEC, for Israel, Central Bureau of Statistics, for Japan, Ministry of Health, Labour and Welfare, for Korea, Korean Statistical Information Service, for Mexico, INEGI, for New Zealand, Statistics New Zealand, for the United States, Centres for Disease Control and Prevention.

\subsection{Over 1 in 6 children live in single-parent households}

14. The number of divorces has increased sharply since the 1970s with a significant proportion of them involving children. As a consequence, 1 in 6 children live in households with a sole parent on average in the OECD, but this proportion varies from less than $6 \%$ in Turkey to over $25 \%$ in Latvia and the United States (Figure 4). 
Figure 4.1 in 6 children live with a single parent

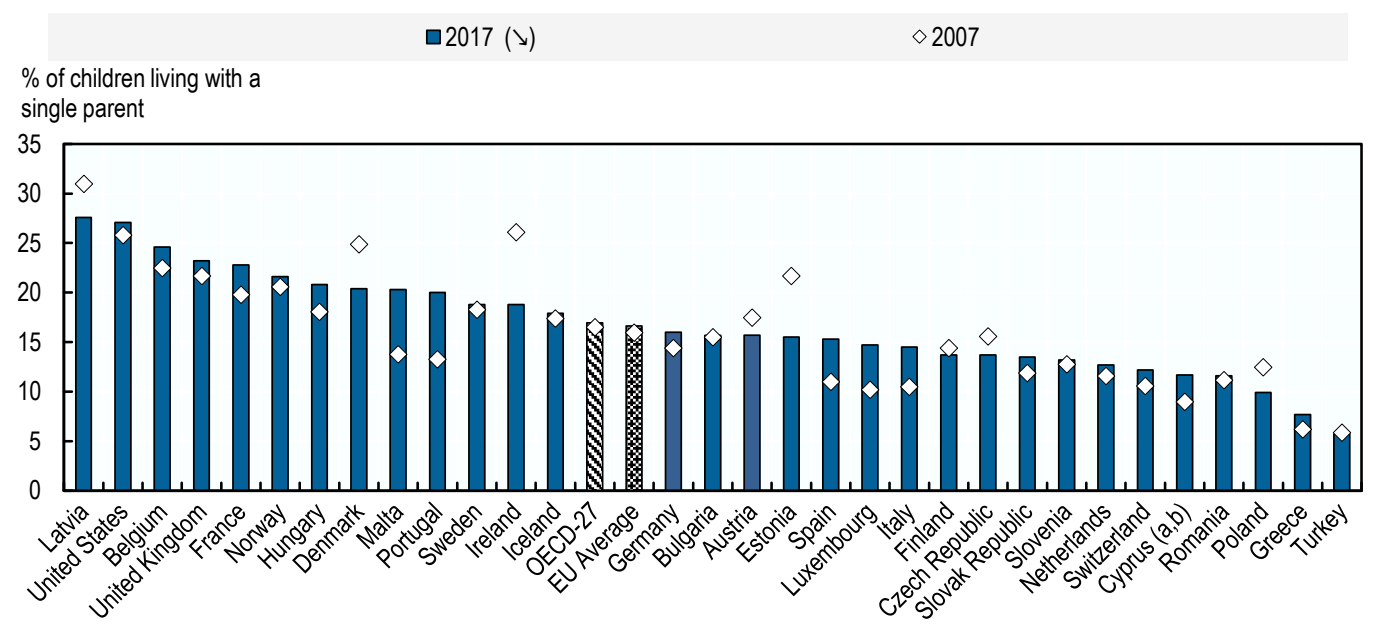

Note: Data for France, Germany, Iceland, Ireland, Luxemburg, Norway, Portugal, Slovak Republic, Switzerland, and the United Kingdom refer to 2016. See note to Chart SF1.2.A.

Source: OECD Family Database, SF1.2 Children in families.

15. The share of children with a single parent has remained fairly stable since the mid2000s, with some exceptions. In Portugal, for example, this share has increased sharply from less than $13 \%$ of children in 2007 to $20 \%$ in 2017. A slight rise occurred also in Belgium, France, Hungary, Italy, Luxembourg, Norway, Spain, Switzerland and the United States.

16. In contrast, the share of children with a single parent fell sharply in Denmark, Estonia, and Ireland (in line with increases in the share of children with two cohabiting parents). This trend is likely the result of changes in attitudes and to family law. For example, Estonia introduced a new family law that eased and simplified divorce procedures, leading to a temporary rise in divorce rates just after the adoption of the new law. In parallel, the prevalence of cohabitation has been increasing steadily since the 1960s, and social and family laws gradually adapted to take this de facto situation into account until the formal introduction of a registered partnership status in Estonia in 2014.

\subsection{1 adolescent in 10 live in a stepfamily}

17. Family reconstitution has become more common across the OECD, and many children live in stepfamilies i.e., with a step-parent and potentially step-siblings. Such reconstituted families may have complex structures that also include biological children of parents from different unions. However, available household surveys generally collect information without distinguishing between children based on their biological relationship with both parents, such that there are no statistics on the share of children in stepfamilies available for all countries.

18. The Health Behaviour Survey in School-aged Children, however, provides some information for adolescents aged 11-15. These data suggest that about 1 in 10 adolescents live in a stepfamily, on average, among participating OECD countries (Figure 5). Yet, this proportion varies greatly from country to country: $12 \%$ or more adolescents live in a step 
family in Belgium, Czech Republic, Estonia, Finland, France, Iceland, Luxembourg and the United States, but only 5\% or less do so in Greece, Italy, and Turkey.

Figure 5. Young adolescents in stepfamilies

Distribution (\%) of children aged 11-15 by type of parental living arrangement in main home, 2013-14

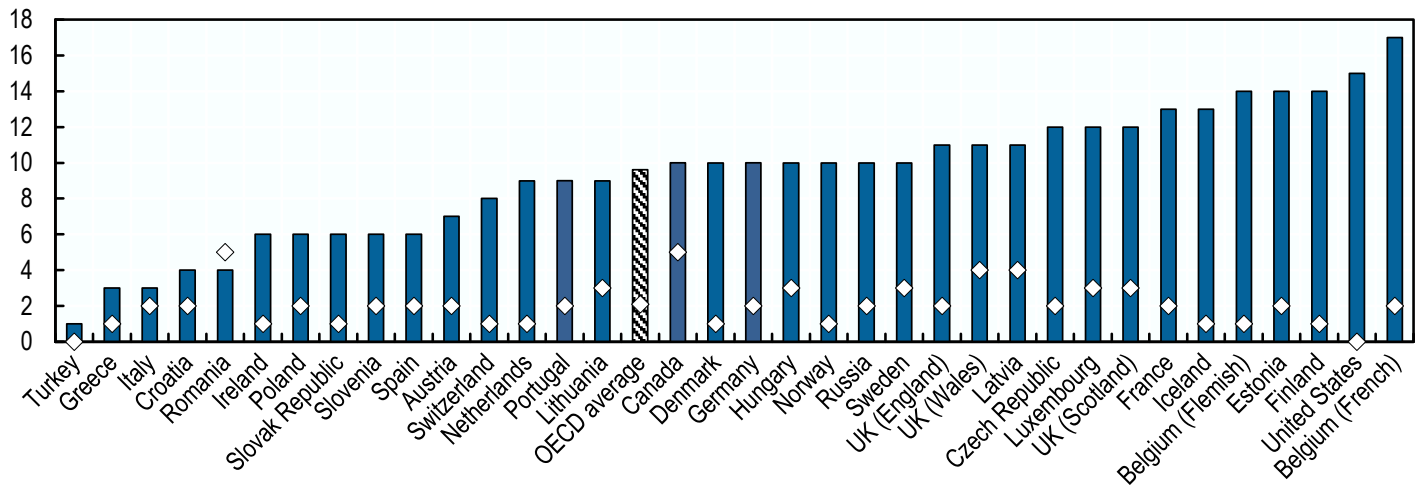

Note: a) 2010 for Slovak Republic, Turkey and the United States; b) Respondents were asked about their parental living arrangements, whether they had 'one' or 'two' homes, and which household was their 'main' home. The data shown here reflect arrangements in the respondent's 'main' home only.

Source: Health Behaviour in School-aged Children Study (HBSC) 2013-14 http://www.hbsc.org/

\subsection{Increased complexity and fluidity of family living arrangements}

19. The categorization of children in Figure 1 by family type is useful for international comparison, but it hides the fact that family living arrangements are increasingly diverse, complex and fluid (Berger, 2016 ${ }_{[10]}$ ) (Pailhé et al., 2014 $4_{[5]}$ ). Although most children live in a stable family and home environment, children and parents do not always cohabit the same dwelling on a permanent basis. This affects, in particular, the situation of single-parent families, which often involves complex residential arrangements and is often a transitory period in children's life (Bernardi and Mortelmans, 2018 $8_{[11]}$ ).

20. Complex family living arrangements exist from childbirth. For example, nearly $20 \%$ of first births in 2016 in the United States involve mothers who do not live with a partner on a permanent basis, and the proportion of children born to single parents is increasing $\left(\mathrm{Wu}, 2017_{[12]}\right)$. Family complexity also increases over the child's early years: at birth, $78 \%$ of firstborns children are the only child, and the other $22 \%$ have half-siblings with whom they share a father. By age 10, $60 \%$ of firstborn children of unmarried mothers have a half-sibling; $23 \%$ have half-siblings only on their father's side; $18 \%$ have half siblings only on their mother's side, and 19\% have half-siblings from each of their parents - that is, they share their mother (and usually their dwelling) with children who have different fathers, and they share their father with children who have different mothers (Cancian, Meyer and Cook, 2011 $\left.{ }_{[13]}\right)$. Such complexity results from a relatively high degree of fluidity between different family situations. Nearly half of U.S. children experience at least one change in their family situation in their first nine years of life, and $17 \%$ experience at least three changes (Bzostek and Berger, 2017 $7_{[14]}$ ). 
21. Across the OECD, the transition to a "new family" takes many forms and often involves several steps before new partners move into the same dwelling on a permanent basis (Bernardi and Mortelmans, 2018 $8_{[11]}$ ). Very often, for a period of time that varies in length, new partners continue to have two dwellings and at least one partner commutes from one dwelling to the other so that they co-reside in the same dwelling only on a parttime basis.

22. As a result, men and women who re-partner after a first union make up a significant proportion of non-cohabiting couples (i.e. so-called "Living apart together"). For example, in Belgium (28\%), France (27\%), the Netherlands (33\%), Norway (28\%) and in Russia $(33 \%)$ more than a quarter of all non-residential relationships are between "divorcees" aged around 40 years old who intend to start living together within the next three years (Mortelmans et al., 2015 $5_{[15]}$ ).

Figure 6. Young adolescents commuting between the two homes of their separated parents

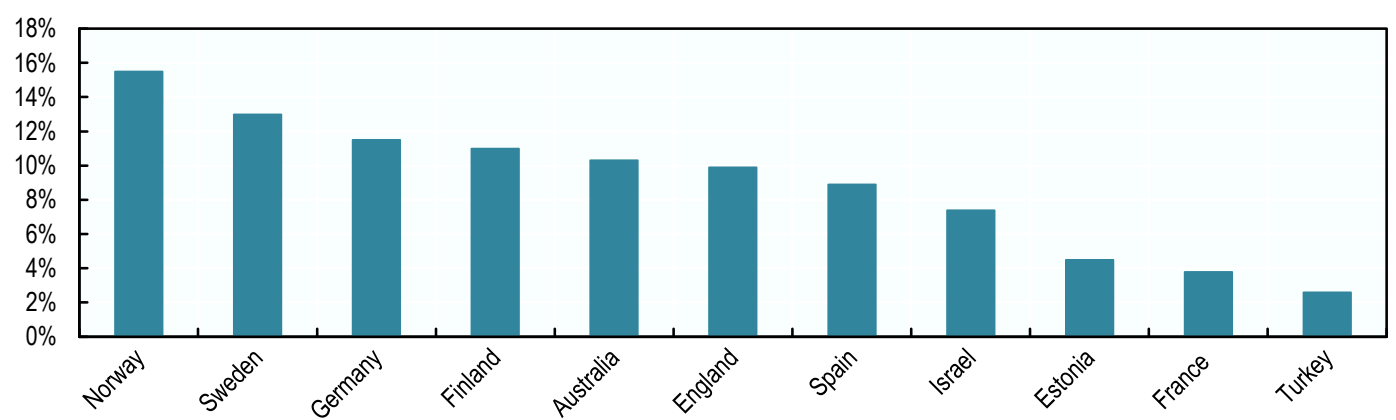

Note: a: a) 2017 for Finland; 2016-17 for Sweden; 2016 for France; 2012-13 for Australia; 2013-14 for other countries; age 10 to 14 for Australia, Finland and France, 13 to 18 years for Sweden and 8 and 10 years for other countries. Differences in the definition of residential status can affect data comparability.

Source: Australia : Family characteristics and transition survey, 2012-13 ; Finland: 2017 Leisure Survey; France: Algava et al. (2019), Insee Première, 1728; Sweden: Barns boende 2016-2017, Statistics Sweden; for other countries: Children's Worlds: The International Survey of Children's Well-Being:; samples are based on mainstream schools and are representative of the entire country or federal region in Germany (Thuringia, Hesse, Baden-Wurttemberg and North Rhine-Westphalia), Spain (Catalonia), Turkey (Istanbul)..

\subsection{Single-parent families are more likely to experience poverty}

23. Family complexity affects how parents allocate both income and time within and across households. Children of separated parents are also increasingly in shared custody and commuting between two homes. This has a cost, because some expenditures, such as housing and furniture, are duplicated, but it may also lead to more equal sharing of clothing or food expenses. Yet, many low-income parents cannot afford to share physical custody of children after they separate, and thus, they (usually the mother) are more likely to opt for single custody. 
24. In particular, the risk of poverty is strongly dependent on the family situation since nearly one in three single-parent households is poor compared to only one in ten families with two parents (Thévenon, $2018_{[16]}$ ). Yet, this estimation of the risk of poverty is based on a very simplified categorisation of family types which ignores the diversity of family living arrangements and their consequences on family needs and disposable income. For example, commuting costs are usually ignored by conventional measures of poverty rates, thereby disregarding the variation in the cost parents bear due to their actual family living arrangement. In addition, an adult who lives in a stepfamily and also has biological children in another household may not share all of his or her income with the "new" household. Yet, this is also ignored by conventional measures of poverty rates which assume that all household members pool their income.

25. Furthermore, household surveys usually do not identify the different dwellings in which children and other family members live and how time and income is distributed, making it difficult to identify how living standards are affected (Box 1). Available studies show that having parents and/or children commuting between different households substantially increases poverty rates. For example, (Toulemon, $2012_{[17]}$ ) suggested that in France, child poverty rates would increase by three percentage points if adult household members who also live elsewhere are assumed to share only half of their income with the surveyed-household. By contrast, the child poverty rate drops significantly if it is assumed that most of individual income is spent in only one household. Such estimates require information on the different dwellings where parents and children live and assumptions about sharing of income and expenses across the different dwellings.

26. Taking family living arrangements more carefully into account is an important issue in order to accurately estimate the poverty risk families face and to better define policy priorities. This requires collecting more detailed information on family living arrangements and on how adults potentially share their income between their household of residence and those where their other children live (Box 1). Doing so can have a significant impact on estimates of child poverty rates, but it involves technical challenges to collect accurate data, with a risk that some parents may not be willing to disclose this information for example in order to avoid being obliged to pay more support for a previous family. 
Figure 7. Single-parent families are on average three times more likely to be poor than twoparent families.

Poverty rates by family status, 2017 or latest year available .

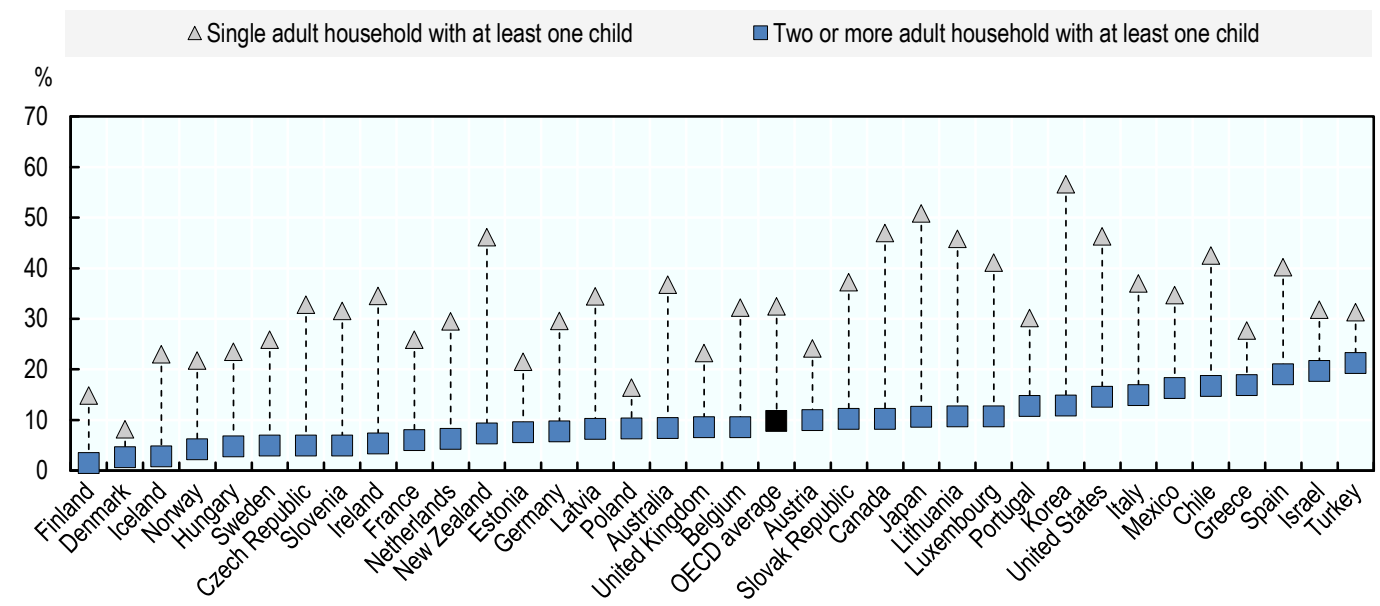

Note: Countries are ranked in descending order according to the poverty rate in all households. a) Data for New Zealand to 2014, for Iceland, Japan, Turkey and South Africa to 2015, and for Chile to 2017.

Source: Income Distribution Database \& OECD Family database (C) 2018.

\section{Box 1. Children's family living arrangements: household categorisations and their limits}

Children's households are grouped into broad categories, which are common in crossnational household statistics and where the family situation is characterised simply by the presence of two, one or no parent :

- Two parent households, include children who live with their two parents, who can be biological, step- or adoptive-parents. These household may also include other adults, such as grandparents - a frequent occurrence in eastern European countries (Iacovou and Skew, 2011 $\left.1_{[18]}\right)$. A further distinction is made between married and cohabiting (e.g. unmarried) parents for countries where this information is available.

- Sole parent households, where the child lives primarily in a household with only one 'parent', but possibly other relative or unrelated adults.

- No parent households, where the child lives primarily in a household with none of his/her parents. This household type covers a variety of possible living arrangements, including the child living with grandparents, other relatives or unrelated adults, or in foster care. Children in institutional care are not included, however, since only private households are surveyed.

Despite guidelines to collect information, comparability of data can be hampered by the various rules and definition used in practice by countries to identify family members and categorize households. For example, countries are recommended to use the place of usual residence as the basis of household membership. There are differences, however, in the rules applied by statistical offices to define the usual residence and in how respondents to surveys even consider what their usual residence is. Definitional (and measurement) issues arise especially when household members actually "commute" between different 
dwellings, in which case they can be identified as a member of either two households, only one , or of no household - depending on the rule applied.

As a consequence, household surveys often poorly reflect the diversity of family living arrangements, which are essential to capture the concrete living conditions of families and children. An increasing number of adults and children live usually in more than one residence due to the increase in cohabitation or adults living apart together (i.e. partners spending some days and nights together but who are registered at different addresses) and in shared custody arrangements for children after family dissolution, and this is often not well-captured in censuses or household surveys (UNECE (United Nations Economic Commission for Europe, 2011 $1_{[19]}$ ).

The growing complexity of family settings raises issues regarding how children who share their life between two dwellings are counted in household statistics since there is a risk of children being counted twice, which introduces a positive bias in the estimates of sole parent families. The risk of double counting is especially high when children spend half of their time in each of their parents' dwelling, which happens frequently when children of separated parents are in shared physical custody. How these situations are treated in statistics can have a significant impact on the estimates of family living arrangements, as shown for instance by (Toulemon, 2016 ${ }_{[20]}$ ) who estimates that between $4 \%$ and $6 \%$ of adults, and $6.4 \%$ of children live in two dwellings (or more) in France. The proportion of children not living with both parents thus falls from a biased estimate of $19.7 \%$ to $17.9 \%$ when these children are not double-counted.

Moreover, the increase in union separation and re-partnering at advanced ages has become more common resulting in an increase in the number of "step-parents" splitting their time between his/her new partner and another dwelling (Pasteels et al., 2015 ; Box 1). In these circumstances, numbers of children in stepfamilies can be underestimated because the estimate depends on whether the step-parent is counted as a household member, which varies across countries (and across surveys within countries) (UNECE, 2011 [21]); (Abela and Walker, $\left.2013_{[3]}\right)$.

\section{Family complexity clash with conventional measures of standard of living}

Family structures affect the economic capacity of individuals to share resources and to benefit from return to scales when making decision about household consumption and expenditures. A conventional way to account for the influence of family structure on individual living standards is to use "equivalence scale" to deflate household income and get a proxy of household living standards that controls for the effect of family composition. All adults and children who are identified as household members are treated similarly in the conventional approach, with only a distinction between adults and children but no difference according to their family type and their actual residential status.

Furthermore, the increase in family separation and reformation has given rise to family situations which can be complex in the sense that many parents and children do not live in only one household on a full-time basis, but instead share their life between different dwellings. However, these situations are usually ignored by conventional measurements of standards of living and poverty rates in which all household members are assumed to pool their resources and their weight on consumption or expenditure patterns - captured by the "equivalence scale" coefficient - is assumed to be the same (Henman et al., 2007 ${ }_{[22]}$ ).

One consequence of this conventional approach is that poverty rates of children in sole parent families may be underestimated if the same equivalence scale is used for children in 
couple and in sole parent families, since there are additional costs and less returns to scale for sole parents compared to couple families (Martin and Périvier, 2018 ${ }_{[23]}$ ). For example, if a child resides with both parents, certain expenses e.g. food) are divided, while others (e.g. housing) are duplicated (Henman et al., 2007[22]).

The costs of children incurred by a parent not residing with the child also affect the standards of living of families and children. Research suggests that non-resident parents who have regular contact with a child face considerable costs for caring for that child, well in excess of the proportion of care given (Henman et al., 2007 [24]). This disproportionate cost results from infrastructure costs in providing basic goods for the child (such as a bedroom, furniture, clothes and toys, etc.) as well as transportation costs. Different assumptions can be made to take these costs into consideration and they can have a large impact on the assessment of the economic cost of family dissolution and how this cost is shared between the separated parents (Jelloul and Cusset, 2015 $5_{[25]}$ ).

Different assumptions can be made, however, to account for the growing diversity of family structures and roles adults and children take on in their household(s). These assumptions can significantly affect the estimation of child poverty. For instance, (Toulemon, 2012 ${ }_{[26]}$ ) compares the effect of different assumptions on child poverty estimates in France given the residential status of parents and children. With a poverty threshold fixed at $60 \%$ of median income, he found that the child poverty rate equals $21 \%$ if all household members are assumed to pool their resources. It edges up to $24 \%$ if adult household members who also live elsewhere are assumed to share only half of their income with the household, and scales down to $14 \%$ if the consumption of adults and children commuting between homes accounts for half the weight of full-time household members. Symmetrically, the share of children living in rich families (e.g. with more than twice the median income) ranges from about 5 to $10 \%$, depending on the assumptions used to account for income sharing and for individual consumption. 


\section{Supporting all children with equal rights}

27. In many countries, historically, family benefits and tax allowances targeted married couple families living together with children. In response to the growing number of divorce involving children, most countries introduced an obligation for the non-custodial parent to pay a child alimony to the parent who has custody of the child.. However, the growing proportion of children living with non-married parents, the increasing number of children with separated parents with shared custody, as well as the growth in the number of step or blended families raise a number of challenges to ensuring that all children benefit from the same economic and social protection. Countries are responding to these challenges in different ways.

28. Assessing whether or not children with unmarried parents have the same rights as the children of married couples requires detailed information on the legal environment, which, unfortunately, is not available for all countries. However, the information assembled in the LawAndFamily Database by INED (Institut national des études démographiques) makes it possible to compare the situation of children by considering the legal status of parental partnerships in a large number of European countries.

29. The LawAndFamily Database includes 21 total countries in the European region, of which 18 are OECD countries (excludes Bulgaria, Malta and Romania) and 20 are EU countries (excludes Iceland and Norway). All countries are either an OECD or an EU member state. The data come from a comprehensive survey completed by selected legal experts on family law on various rights and legal consequences associated with each legal family form in each jurisdiction. The legal experts were asked to respond to a variety of questions using a pre-determined rubric (Yes; Yes, but; No; etc.), documenting changes to the answer going as far back as possible given available legal sources or at least from 1965. The selection and wording of the questions as well as the responses provided underwent a peer-reviewed process of seven steps: 1) expert 2) review by another expert 3) expert 4) review by coordinators 5) expert 6) editing by coordinators 7) expert). In this way, the database represents a rich and high-quality source of qualitative information on this issue.

30. We use data from the LawandFamilies Database to produce a set of measures that summarize the overlap in legal effects between traditional and non-traditional family types, within each jurisdiction. For each question, a category is assigned corresponding to the degree of legal protection: 1 - treated differently from marriage (no/less legal effects); 2 share some, but not all, rights with married couples; 3 - same legal effects as those married.

31. The measures we consider can be grouped into three themes: (1) access to state benefits, with questions on income tax and social benefits; (2) protections in the case of death, which includes questions on tenancy continuation, property at death, and survivor's pension (3) protections in the case of union dissolution, which includes questions concerning property, and alimony. The measures consider the most recent data available, either from 2015 or 2016, depending on the country. Furthermore, while the database also covers same-sex couples, due to lack of contextual data and research on other "nontraditional families", this report will only address legal protections of different-sex couples.

32. The next paragraphs highlight policy development that can be adopted to ensure that children living in non-traditional family settings get access to welfare benefits that fully suit their family living arrangements. 


\subsection{Registered partnership as an alternative to marriage and informal cohabitation}

33. A first question concerns the rights and protections guaranteed to children whose parents are not legally married (Perelli-Harris and Gassen, 2012 [27]) (Sánchez Gassen and Perelli-Harris, $\left.2015_{[28]}\right)$. Broadly, some countries require cohabiting parents to either marry or to register their unions if they want their children to benefit from legal protections and rights that resemble those provided for a family with married parents. However, civil or registered partnerships exist in only two thirds of OECD countries (21 out of 36 countries) (Table 1). In addition, in many countries (including Czech Republic, Finland, Germany, Hungary, Italy, Slovenia and the United Kingdom) only same-sex couples can formally register their union, which means that children with opposite-sex unmarried parents may not be protected in the same way. Moreover, in some countries (notably Canada, Mexico, Spain, Switzerland and the United States), access to civil partnership registration depends on the region, which has the final responsibility to create such a status. Thus, the introduction of a civil union status as an alternative institution to marriage remains an option available to some countries. 
Table 1. Recognition of registered partnerships and cohabitation

\begin{tabular}{|c|c|c|c|c|}
\hline & $\begin{array}{c}\text { Registered } \\
\text { Partnership } \\
(\nearrow)\end{array}$ & Year enacted & Cohabitation & Year enacted \\
\hline Netherlands & $\checkmark$ & 1998 & $\checkmark$ & 1971 \\
\hline Belgium & $\checkmark$ & 1999 & $\checkmark$ & 1996 \\
\hline France & $\checkmark$ & 1999 & $\checkmark$ & $\sim 1972$ \\
\hline $\begin{array}{l}\text { United States } \\
\text { (California) }\end{array}$ & $\checkmark$ & 1999 & $\checkmark$ & 1976 \\
\hline New Zealand & $\checkmark$ & 2004 & $\checkmark$ & 1976 \\
\hline Greece & $\checkmark$ & 2008 & $x$ & \\
\hline Israel $^{6}$ & $\checkmark$ & 2010 & $\checkmark$ & 1949 \\
\hline Luxembourg & $\checkmark$ & 2010 & $x$ & \\
\hline Chile & $\checkmark$ & 2015 & $\checkmark$ & 2015 \\
\hline Estonia & $\checkmark$ & 2016 & $x$ & \\
\hline Colombia & $\checkmark$ & $\ldots$ & $\checkmark$ & $\ldots$ \\
\hline Austria & $\checkmark$ & 2019 & $\checkmark$ & $\sim 1920$ s \\
\hline Australia & $x$ & & $\checkmark$ & 2009 \\
\hline Canada (Ontario) & $x$ & & $\checkmark$ & 1990 \\
\hline Czech Republic & $x$ & & $\checkmark$ & 1964 \\
\hline Denmark & $x$ & & $x$ & \\
\hline Finland & $x$ & & $\checkmark$ & 2011 \\
\hline Germany & $x$ & & $\checkmark$ & 1972 \\
\hline Hungary & $x$ & & $\checkmark$ & 1978 \\
\hline Iceland & $x$ & & $\checkmark$ & 1946 \\
\hline Ireland & $x$ & & $\checkmark$ & 1996 \\
\hline Italy & $x$ & & $\checkmark$ & 2000 \\
\hline Japan & $x$ & & $\checkmark$ &.. \\
\hline Korea & $x$ & & $x$ & \\
\hline Latvia & $x$ & & $\checkmark$ & .. \\
\hline Lithuania & $x$ & & $\checkmark$ & .. \\
\hline Mexico & $x$ & & $\checkmark$ & 2006 \\
\hline Norway & $x$ & & $\checkmark$ & 1991 \\
\hline Poland & $x$ & & $\checkmark$ & 1997 \\
\hline Portugal & $x$ & & $\checkmark$ & 1999 \\
\hline Slovenia & $x$ & & $\checkmark$ & 1976 \\
\hline Slovak Republic & $x$ & & $x$ & \\
\hline Spain & $x$ & & $x$ & \\
\hline Sweden & $x$ & & $\checkmark$ & 1974 \\
\hline Switzerland & $x$ & & $x$ & \\
\hline Turkey & $x$ & & $x$ & \\
\hline United Kingdom ${ }^{3}$ & $x$ & & $\checkmark$ & $1973^{4}$ \\
\hline
\end{tabular}

Note: Data from 2016 for Ireland, Italy, and the UK. Data from 2015 for Belgium, Bulgaria, Czech Republic, Finland, France, Germany, Greece, Hungary, Iceland, Ireland, Malta, Netherlands, Norway, Poland, Portugal, Romania, Slovenia and Sweden. (2) $" \checkmark "$ indicates the family form is legally recognized for opposite sex couples. " $\mathbf{x}$ " indicates the family form is not legally recognized.. (3) UK refers to three jurisdictions (England and Wales, Northern Ireland, and Scotland). (4) In the jurisdiction of Scotland, enacted in 2006. (5) The data for Israel are supplied by and under the responsibility of the relevant Israeli authorities. The use of such data by the OECD is without prejudice to the status of the Golan Heights, East Jerusalem and Israeli settlements in the West Bank under the terms of international law. 
Source: Law and Families Database (INED) for Austria, Belgium, Bulgaria, the Czech Republic, France, Finland, Germany, Greece, Hungary, Iceland, Ireland, Italy, Malta, the Netherlands, Norway, Poland, Portugal, Romania, Slovenia, Sweden, and the United Kingdom; https://uk.practicallaw.thomsonreuters.com/Browse/Home/International/FamilyLawGlobalGuide for Canada (Ontario), Chile, Denmark, Israel, Japan, Mexico, New Zealand, Spain, Switzerland, Turkey and the United States (California); http://ceflonline.net/wp-content/uploads/Slovakia-IR.pdf for the Slovak Republic; https://www.loc.gov/law/foreign-news/article/estonia-family-relations-extended-beyond-marriage/ for Estonia; http:/english.hani.co.kr/arti/english_edition/e_national/780753.html_for Korea; https://www.utrechtlawreview.org/article/10.18352/ulr.347/ for Estonia, Latvia and Lithuania; https://www.familylawweek.co.uk/site.aspx?i=ed178214 for Colombia; and https://guichet.public.lu/en/citoyens/famille/vie-maritale/partenariat-pacs/declaration-partenariat.html for Luxembourg.

34. Another option is to extend the rights of families whose partners cohabit "de facto" i.e., outside of any formal union but under certain circumstances. This extension often covers certain areas or specific events in life such as the separation of parents or the death of one parent. It also depends on the recognition criteria for cohabitation, which may be objective (e.g. having lived together for a specified length of time) or subjective (e.g. referring to "family bonds" or a "stable emotional and economic community"). Recognition of an informal union is often attached to certain rights, but these rights are generally limited compared to those granted to married couples and. In addition, this "de facto" recognition may also carry some disadvantages compared to the case where each partner is treated as a single person. As a result, differences in eligibility for certain benefits or types of protection by parental union status remain large (Figure 8 ).

\subsection{Make tax and benefit eligibility rules more neutral vis-à-vis parental marital status.}

35. Partnership legal status can be an important factor in the calculation of income tax liabilities and/or eligibility for means-tested benefits. Where registered partnerships exist for different-sex couples, their tax treatment is often equal to that of married couples, e.g. they are taxed jointly (where a joint tax system exists) or as married partners. By contrast, as shown in Figure 3, some countries (Australia, the Netherlands, Portugal, Slovenia and Sweden) grant couples who cohabit informally the same tax advantages as married couples. In many other countries where married partners are taxed jointly (including Belgium, and Greece), informally cohabiting partners are eligible for the same tax treatment only if they have a child together. Partners who cohabit informally are not eligible for the same tax rights as married couples in the Czech Republic, France or Germany, even if they have a child together.

36. Several countries tax married partners on an individual basis but grant tax deductions on a household basis. In Slovenia and Sweden, the same rules also apply to informally cohabiting partners regardless of whether they have a child. In Finland, Iceland and Italy, informally cohabiting couples are entitled to the same tax reductions as married couples only if they have a child together. By contrast, in Ireland and the United Kingdom, cohabiting partners do not have the same rights as married couples. In Poland, married partners have the choice between joint or individual taxation, but cohabiting couples do not have that choice. 
Figure 8. Tax treatment and eligibility to social assistance by legal family form, 2016

\begin{tabular}{|c|c|c|c|c|c|}
\hline \multicolumn{4}{|c|}{ Tax treatment } & \multicolumn{2}{|c|}{ Social assistance benefits } \\
\hline \multicolumn{2}{|c|}{ Joint taxation for married couples } & \multicolumn{2}{|c|}{ Individual taxation for married } & & \\
\hline $\begin{array}{l}\text { Same rights for } \\
\text { all informal } \\
\text { cohabitants }\end{array}$ & $\begin{array}{l}\text { Same rights for } \\
\text { informal } \\
\text { cohabitants } \\
\text { with children }\end{array}$ & $\begin{array}{l}\text { Same rights for } \\
\text { all informal } \\
\text { cohabitants }\end{array}$ & $\begin{array}{l}\text { Same rights for } \\
\text { informal } \\
\text { cohabitants } \\
\text { with children }\end{array}$ & $\begin{array}{l}\text { informal } \\
\text { cohabitants }\end{array}$ & $\begin{array}{l}\text { for informal } \\
\text { cohabitants }\end{array}$ \\
\hline Netherlands & Belgium & Australia & Austria & $\begin{array}{l}\text { Austria } \\
\text { Belgium }\end{array}$ & Greece \\
\hline \multirow[t]{4}{*}{ Portugal } & Greece & Slovenia & Finland & Czech Republic & Iceland \\
\hline & Norway & Sweden & Hungary & $\begin{array}{l}\text { Finland } \\
\text { France }\end{array}$ & Italy \\
\hline & & & Iceland & Germany & Norway \\
\hline & & & Italy & Hungary & \\
\hline \multicolumn{2}{|c|}{ No rights for informal cohabitants } & \multicolumn{2}{|c|}{ No rights for informal cohabitants } & Netherlands & \\
\hline \multicolumn{2}{|c|}{ Czech Republic } & \multicolumn{2}{|c|}{ Ireland } & $\begin{array}{l}\text { Poland } \\
\text { Portugal }\end{array}$ & \\
\hline \multicolumn{2}{|c|}{ France } & \multicolumn{2}{|c|}{ Poland } & Slovenia & \\
\hline \multirow{2}{*}{\multicolumn{2}{|c|}{ Germany }} & \multirow{2}{*}{\multicolumn{2}{|c|}{ United Kingdom }} & Sweden & \\
\hline & & & & United Kingdom & \\
\hline
\end{tabular}

Note: 1) Data from 2019 for Austria, 2016 for Ireland, Italy, and the United Kingdom. Data from 2015 for Belgium, the Czech Republic, Finland, France, Germany, Greece, Hungary, Iceland, Ireland, the Netherlands, Norway, Poland, Portugal, Slovenia and Sweden. 2) The United Kingdom refers to three jurisdictions (England and Wales, Northern Ireland, and Scotland) 3) Lower income taxes refers to the question: "Can a relationship of this type result in lower income tax than for two individuals without a partner?" 4) Social benefits refers to the question: "When one partner (long-term unemployed or even never having been employed at all) would be entitled to a basic social benefit, will the income of the other partner then be taken into consideration and will it possibly result in loss or reduction of this entitlement?"

Source: Author categorisation based on the information given by the LawsAndFamilies database, https://www.lawsandfamilies.eu/.

37. Whether this difference in tax treatment harms or benefits cohabiting couples depends on whether the tax due is lower if each spouse is taxed separately versus when both are taxed jointly. In the latter case, a "cohabitation bonus" (or a "marriage penalty") is a gain in income due to either less favourable tax rules or to a loss in state-provided benefits that an individual may experience upon marriage, normally due to them facing a higher tax rate upon joint taxation. Also, the tax system has rules about who can count a child as their dependent, which then enables the eligible parent(s) to shield a portion of their income from taxation. Conversely, a cohabiting couple may suffer a penalty if they are not eligible for certain tax reductions enjoyed by married couples, most often in the form of tax credits (Box 2). 
38. For example, in the United States where the federal tax code treat married couples as one tax unit and cohabiting couples as two tax units, some married couples owe more tax than they would if they were unmarried, while other married couples pay less than would if they had remained single (Besharov and Gilbert, 2015 ${ }_{[29]}$ ) (Maag and Acs, $\left.2015_{[30]}\right)$. The difference in tax liability according to marital status depends on the distribution of income between the two partners, and how children are reported in the tax return. Typically, married partners with very low income and two children pay lower taxes than cohabiting couples if the higher earner claims both children for tax purposes because they qualify for larger tax credits that phase in as income rises. Couples with higher income instead face penalties if they marry, regardless of whether the children are split between households before marriage. The size of bonuses and penalties varies across states because of variations in state tax policies and the rules governing some public assistance programmes.

39. The French "quotient conjugal" introduced in 1945, exemplifies a difference in tax treatment on the basis of marital status. Under this scheme, married and registered partners benefit from an uncapped tax reduction, which increases with the couple's income and the difference in income between them. In addition to this advantage, the presence of children results in an additional tax reduction (the "family" part of the quotient), which is capped at a certain income level, but does not depend on parents' marital status. The complexity of fiscal rules implies large variation in the amount of tax support given across households.

40. Different options are available to introduce greater neutrality in the tax system visà-vis partners' marital status (Allègre, Périvier and Pucci, 2019[31]). For instance, individualisation of the tax base could be considered. However, this would lead to many households in France paying higher taxes, which makes such a reform politically difficult to introduce. An alternative is to cap the tax reduction given to married and registered partners. In this case, the number of "losers" will be smaller, yet the group of children living with informally cohabiting parents will continue to be treated differently, depending on their parent's marital status.

41. Another option, applicable to France as well as other countries, would be to extend the tax/benefit provision for married and registered couples to informally cohabiting couples. However, this is likely to be fiscally costly. Moreover, such a reform requires clear criteria to identify couples who are in a de facto relationship.

\section{Box 2. The cohabitation bonus in OECD countries}

Figure B2.1 illustrates, for OECD countries, the advantage that cohabiting parents can enjoy over married couples if they are taxed separately and receive benefits to which their personal income level entitles them. By comparing the difference in net income position of cohabiting parents (treated by tax and benefit systems as two single-parents with one child each) and married couple (families with two children), the figure highlights the advantage that two parents, each with a child from a previous union, may gain from cohabitating versus marrying or registering their partnership.

Generally, cohabitation bonuses exist in most countries, of which the severity depends on the total income earned by the spouses (Figure B2.1). The gap in net income decreases with income in most countries, which is to be expected since eligibility to means-tested benefits also phases out. The gap is very wide in many countries for very low-income couples (Panel A), with cohabiting couples who report their incomes separately receiving higher amounts of family or housing, or being eligible to 
receive social assistance benefit. In Ireland, the difference in the amount of in-work benefit explains a large part of the substantial difference in net income. Differences in disposable income are much smaller for high-income couples (Panel C), with relatively small differences which arise from the amount of tax paid since the role of benefits decreases as earnings grow.

\section{Figure B2.1 Net income gap between married and cohabiting couples ${ }^{1}$}

Panel A: Proportion of total gross couple earnings, P10-P10².

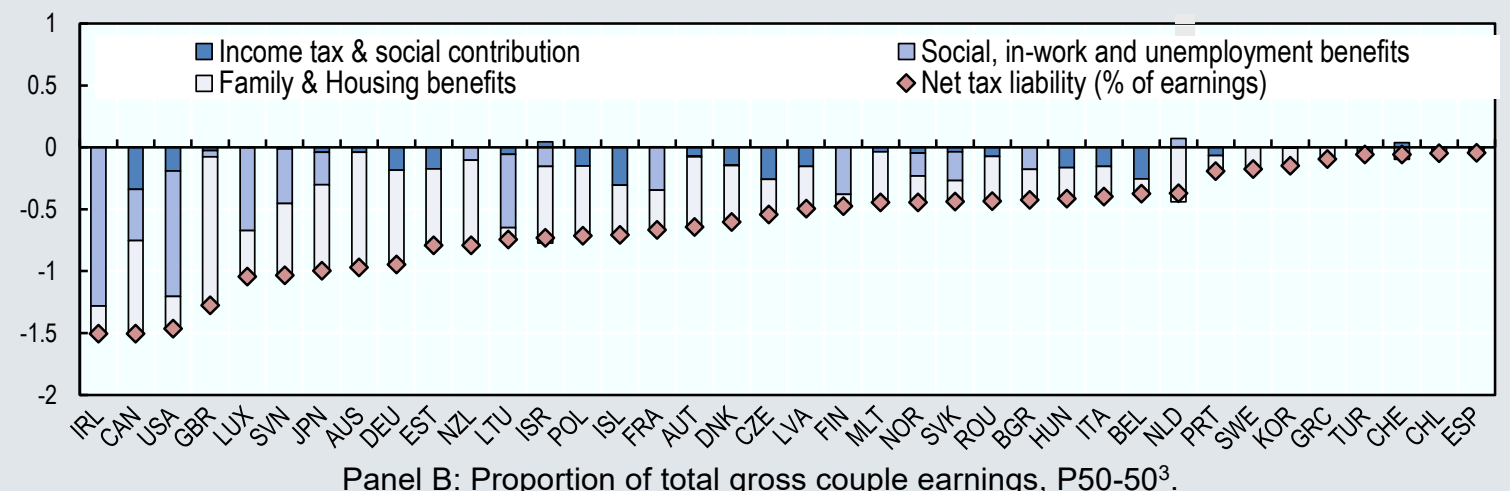

Panel B: Proportion of total gross couple earnings, $\mathrm{P} 50-50^{3}$.

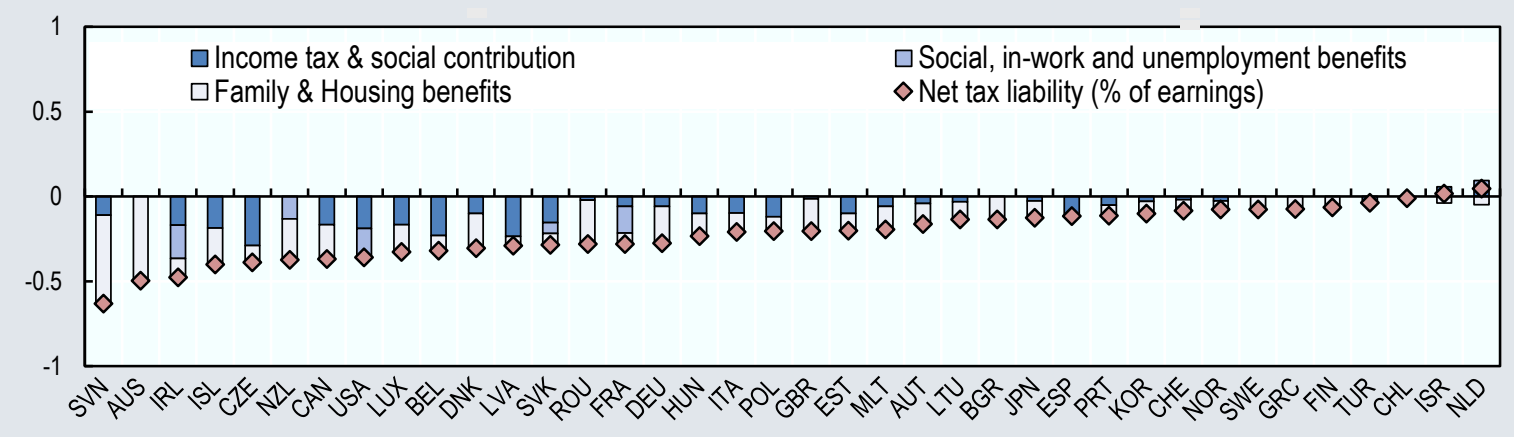

Panel C: Proportion of total gross couple earnings, P90-904.

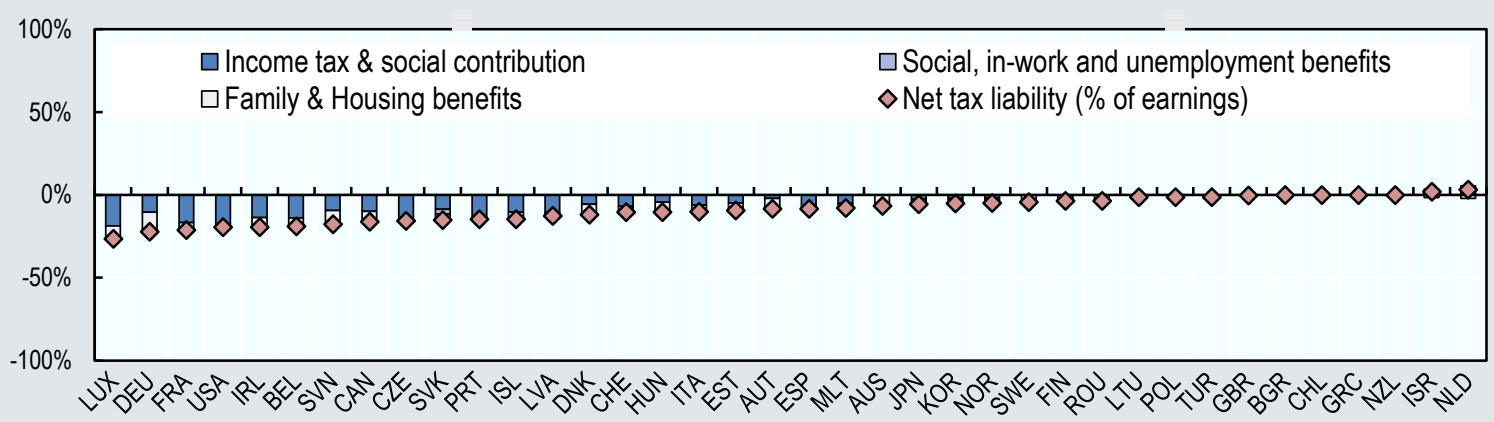

Note: 1) The table shows simulated annual marriage penalties as a proportion of total earnings for hypothetical couples for three different earnings combinations. P10 refers to earnings of the lower 10\% of the country's income distribution; P50 to average earnings, and P90 refers to earnings of the top $10 \%$ of the country's income distribution. A negative number implies a marriage bonus. The simulation takes into account policies in effect 1 July 2015. The marriage penalty is defined as the increase in the combined tax liability net of transfers of two individuals following a marriage, i.e. the tax liability of a couple of a certain household type (based on earnings) minus the sum of the tax liability they would have as two individuals, holding individual earnings constant. The couple is assumed to have two children aged 4 and 6 . Each individual is assumed to take custody of a child, with the second earner having custody of the younger child.

Source: Authors calculation from OECD tax \& benefit model. 


\subsection{Set criteria to assess the economic resources of cohabiting couples}

42. As noted above, an increasing number of children are living with cohabiting parents, and cohabitation can be motivated by different reasons, including the willingness to stay outside the cultural institution of marriage. Yet, informal cohabitation also often reflects different attitudes towards income and expense sharing. Some parents do not cohabit permanently and share only part of their income because they also contribute to another household. For other parents, unmarried cohabitation is a permanent life choice to maintain a certain degree of independence, especially in terms of resource management (Hiekel, Liefbroer and Poortman, 2014 $4_{[32]}$ ).

43. Social benefit programs that limit eligibility to families with incomes below a certain level (i.e., is means-tested) must include an explicit definition of who is included in the family, such that the level of total income can be calculated based on the sum of the incomes of the members of the unit.

44. Broadly, the eligibility to (means-tested) benefits can be defined in two ways: by the income of the "family bond" (individuals living together related by blood, marriage or adoption) or the "economic unit" (individuals living together who share resources). For instance, in the United States, the family unit is used to calculate eligibility for child-care vouchers, housing vouchers, Medicaid, and, in all but a few states, Temporary Assistance for Needy Families (TANF) (Berger and Carlson, 2020 $0_{[4]}$; Lopoo and Raissian, 2014 ${ }_{[33]}$ ). For these programs, the income of a cohabiting adult who is not the children's biological parent is disregarded. In contrast, eligibility for the Supplemental Nutrition Assistance Program (SNAP), the Special Supplemental Program for Women, Infants and Children, school meals, and the Low Income Home Energy Assistance Program is based on the economic unit, thereby encompassing all household members that prepare and eat meals together. As a result, the economic unit could include cohabiters, half and stepsiblings, grandparents, other adults, etc. Similarly, European countries generally take into account the economic household unit when calculating means-tested social benefits.

45. In general, partners living together are assumed to pool their income and share their expenses regardless of civic status, although in practice adjudicating caseworkers may have some discretion. For married and registered partners, the "income pooling" assumption is consistent with the obligation of mutual assistance that underlies their union, although this may not reflect the actual budget management. Furthermore, assuming that all cohabiting and/or married partners pool their income together can be misguided, for instance, for stepfamilies where parents must also provide for children who do not live in the same household (Gray, 2018) (Eickmeyer, Manning and Brown, 2019[34]). In addition, aligning the treatment of cohabiting couples with that of married couples who are assumed to pool their income may not be an option because it creates an incentive to conceal informal relationships (Besharov and Gilbert, 2015[29]). For example, (Perelli-Harris et al., 2012[35]) remark that in France, some empirical works argue the "single mother benefit" (allocation pour parent isolé) enacted in 1976 which gave a monthly income to single mothers up to three years after birth, might have contributed to an increase in births within cohabitation in the 1980s by creating an incentive to delay marriage. If one of the partners receives social benefits, the new partners may not want to risk losing them by declaring they cohabit and even may prefer to stay in a "Living Apart Together" relationship. 
46. It is important that the criteria used for eligibility for social benefits accurately reflect the household's budget constraints and sharing of expenses. For instance, in Denmark, resource sharing is assumed if cohabiters are 25 or older, have a shared residence and have either a child or some other indicator that they are a couple, such as a joint bank account or a shared mortgage. In France, the jurisprudence of the Conseil d'Etat indicates that only a bundle of concordant evidence makes it possible to establish a situation of cohabitation. Different pieces of information can be used, such as joint property, water and electricity consumption, the existence of a single home insurance contract or the presence of a child for whom one parent assumes financial responsibility and the other receives family benefits. If individuals wish to be treated as independent units, then evidence that partners pay separate rent and food outlays can be requested. In any case, it is important to use easily enforceable criteria and to ensure that the same criteria are shared by the various social and tax administrations.

\subsection{Grant equal rights to parental leave}

47. Children of cohabiting couples may also be disadvantaged regarding their parent's access to parental leave. Every country, for which information is available, gives parental leave to both legal parents regardless of marital status, but in some countries these rights are conditional to some criteria. For instance, in Belgium, partners must have been living together for at least three months. In Greece and Iceland parental leave rights for cohabiters are conditional on the effective custody of children. Conversely, few countries in the sample Germany, Hungary and Poland) grant no rights to parental leave to a cohabiting partner if he/she is not the legal parent (Figure 9). 
Figure 9. Rights to parental leave of cohabiting partners

\begin{tabular}{|c|c|c|c|}
\hline \multicolumn{2}{|c|}{ Both partners are legal parents } & \multicolumn{2}{|c|}{ One parent is the legal } \\
\hline $\begin{array}{c}\text { Same rights for } \\
\text { each parent }\end{array}$ & $\begin{array}{c}\text { Conditional } \\
\text { rights for } \\
\text { parents }\end{array}$ & $\begin{array}{c}\text { Same rights for } \\
\text { each parent }\end{array}$ & $\begin{array}{l}\text { Partial rights } \\
\text { for the partner }\end{array}$ \\
\hline Austria & Belgium & Austria & Belgium \\
\hline Czech Republic & Greece & Czech Republic & Sweden \\
\hline Finland & Icoland & Finland & \\
\hline France & & France & \\
\hline Germany & $\begin{array}{l}\text { United } \\
\text { Kingdom }\end{array}$ & Germany & No rights for \\
\hline Hungary & & Greece & \\
\hline Ireland & & Iceland & \\
\hline Italy & & Ireland & Germany \\
\hline Netherlands & & Italy & Hungary \\
\hline Norway & & Netherlands & Poland \\
\hline Poland & & Norway & \\
\hline Portugal & & Portugal & \\
\hline Slovenia & & Slovenia & \\
\hline Sweden & & $\begin{array}{l}\text { United } \\
\text { Kingdom }\end{array}$ & \\
\hline
\end{tabular}

Note: 1) Data from 2019 for Austria, 2016 for Ireland, Italy, and the United Kingdom. Data from 2015 for Belgium, the Czech Republic, Finland, France, Germany, Greece, Hungary, Iceland, Ireland, the Netherlands, Norway, Poland, Portugal, Slovenia and Sweden. 2) The United Kingdom refers to three jurisdictions (England and Wales, Northern Ireland, and Scotland) 3) Parental leave for both parents refers to the question: "When both partners are the legal parents of a child, does each partner then have a statutory right to paid or unpaid parental leave?" 4) Parental leave for partners refers to the question: "When only one partner is the legal parent of a child, does each partner then have a statutory right to paid or unpaid parental leave?".

Source: Authors categorisation based on the information given by the LawsAndFamilies database, https://www.lawsandfamilies.eu/

\subsection{Strengthen protection in the event of the death of an unmarried parent}

48. Finally, parents' marital status often influences the protection and income that children and other family members receive in case of parental death. From a child's perspective, these differences are particularly important since the death of one parent is likely to result in a substantial decline in family income. Yet, in order to determine how housing and household assets are divided up, as well as whether the household will have access to a survivor pension, states often depend upon the marital status of the parents prior to the death.

49. Figure 10 considers policies which take effect after the death of one's partner. Tenancy continuation (the right to remain in the housing rented by a deceased partner) and property rights at death are particularly important for children to maintain a stable environment. 
Tenancy continuation is key to maintain some stability in children's life after such a dramatic event as the death of a parent. It involves that children are then able to stay in the same school, keep the same leisure activities and the same network of friends which may be critical to a child's material and emotional well-being in an already emotional time. The right to tenancy continuation, when the partner was in a formal union with the deceased, exists in all of the countries covered in Figure 10. Protections in the case of death

50. , even to the cohabitating partner. However, some countries put extra eligibility requirements for cohabiters, such as a minimum residential requirement (France, Ireland, the Netherlands and Norway), to require the consent of the landlord (the Czech Republic) or to condition this right on the presence of children (Norway). No systematic rule exists in Finland where the entitlements are subject to interpretation by the relevant public authorities, and this right is not extended to cohabiters in Belgium and Greece. As a result, these countries give only partial rights to cohabiters, since married people and those in registered partnerships are automatically given the right to tenancy continuation.

51. In some states, property acquired during a marriage is automatically considered joint property, such that in the event of death, the surviving spouse automatically owns $50 \%$ of the possessions (absent a prenuptial contract). Given the informal nature of cohabitation, states often do not extend this type of joint property regime to cohabiters (Belgium, the Czech Republic, Greece, Hungary, Poland, and Portugal), while others limit this right to a specific type of property (Sweden), only in the case of a contract (France, Norway, Italy), or if the cohabiter can argue that they contributed to the acquisition of the property (Finland, the Netherlands, Iceland, and Norway). In contrast, states can also choose to not have an automatic system for joint property for married spouses, as in Austria, Germany, Iceland, Ireland, Italy and the United Kingdom. In these cases, a joint property regime can be established by choice (Italy), or through a contract (Austria). Otherwise, all property of the deceased can be subject to inheritance laws, as in Germany, Iceland, Ireland and the United Kingdom. Inheritance laws often defer to the spouse where there is no will, so this type of system gives only partial rights to cohabiters. 
Figure 10. Protections in the case of death

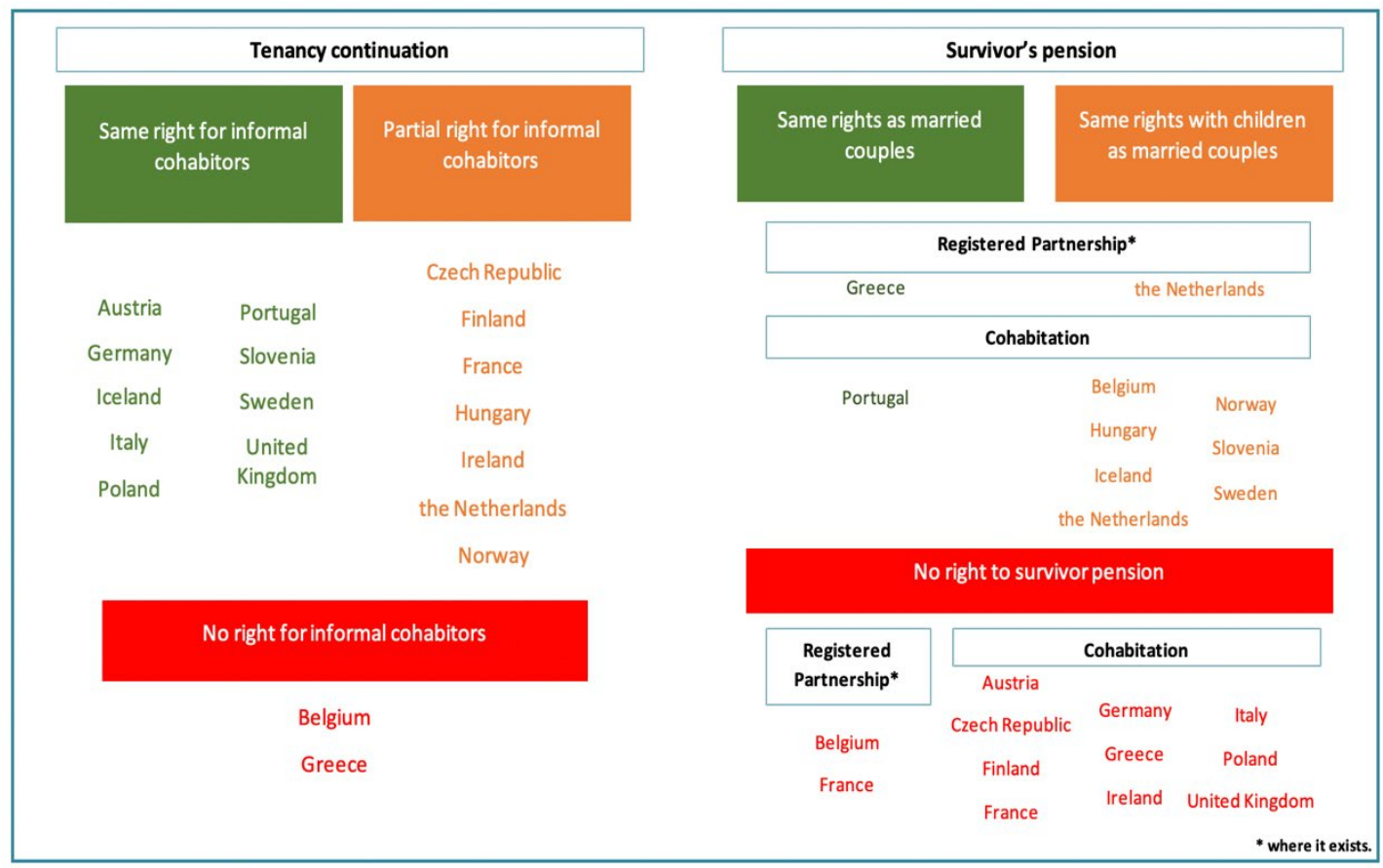

Note: Data from 2019 for Austria, 2016 for Ireland, Italy, and the United Kingdom. Data from 2015 for Belgium, the Czech Republic, Finland, France, Germany, Greece, Hungary, Iceland, Ireland, the Netherlands, Norway, Poland, Portugal, Slovenia and Sweden. The United Kingdom refers to three jurisdictions (England and Wales, Northern Ireland, and Scotland). Tenancy continuation refers to question: "When the partner who holds the rental contract dies, does the other partner have a right to continue to rent the home?" Survivor's pension to : "When one partner dies while being employed, is the surviving partner then normally entitled to a survivor's pension?"

Source: Author coding based on the information given by the LawsAndFamilies database, https://www.lawsandfamilies.eu/.

52. Survivor's pension refers to state transfers paid to a dependent surviving spouse. Even within marriage, this right is often subject to eligibility criteria, such as being married for a minimum period of time, being above or close to the retirement age, or having custody of an underage child. Among the countries covered, few extend this right to non-married partners. Of those that allow different sex registered partnerships, Greece and the Netherlands extend the married right to survivor's pensions to registered partnership. And, only Hungary, Iceland, the Netherlands, Norway, Portugal, Sweden, Slovenia, and the United Kingdom extend the possibility of survivor's pension to cohabiters. Within that group, Hungary, Iceland, Norway and the United Kingdom impose extra eligibility requirements to cohabiters, such as a minimum length of time spent together and/or having had a child together, or if the deceased explicitly named the partner in their will.

53. Inheritance rules in the absence of a will also vary according to parent's marital status, in particular whether the surviving partner is automatically considered an inheritor. In the absence of a will, normally the (married) spouse inherits the entire estate or a share of the estate, in the case the deceased has surviving descendants. Though the exact conditions and proportion of the estate of inheritance vary by country, all countries covered allow spouses some type of right. Yet only Greece and the Netherlands extend this right fully to registered partnerships, and only Slovenia also gives cohabiters the same right. Others extend this right depending on a set of conditions being met, such as having children 
together (Ireland and Norway), after a length of time spent living together (the Czech Republic, Ireland, Portugal ${ }^{2}$ ), or after proof they depended on the deceased (the Czech Republic and Ireland). Yet, even then, only the Czech Republic and Norway extend the full range of spousal inheritance rights. Ireland, Sweden and the United Kingdom allow a provision from the estate, and Portugal provides only rights to the residence, as is the case in Belgium for registered partnerships.

54. In all, while there is great diversity in the degree of coverage. Each country extends some type of legal effects of married couples to their non-married counterparts (either registered partnership or cohabitating) with regard to protections in the case of death or to inheritance rights. Only Greece extend the same rights they offer married individuals, but only to those in registered partnerships. Otherwise, only Slovenia fully extends all rights to cohabiters, although Norway and Sweden extend full rights in most but not all areas. Moreover, most countries do not extend survivor's pensions and inheritance rights to cohabiters (Austria, Finland, France, Germany, Greece, Hungary, Poland, and Portugal). In these circumstances, the standard of living of children after the death of a parent is likely to vary greatly depending on the pre-existing marital status. More careful consideration of the interests of children can encourage countries to equate rights of across union type in these different areas, at least given the presence of a child in the household.

\subsection{Adapt child maintenance support to modern family living arrangements}

Family dissolution has important and negative material (and immaterial) consequences on families, children's living standards and poverty rates. Parental separation induces "costs" which are shared between separated parents in proportions that vary along many factors, including: (i) the division of property at dissolution; (ii) the payment of alimony by one parent to the other (or by the State if there is no private payment); (iii) the solution adopted for child custody, and (iv) the welfare support granted to sole parent families (OECD, $2011_{[36]}$ ) (Beaumont, Mason and Schulze, 2014[37]).

\subsubsection{Align alimony and property rights across all forms of partnerships}

55. Parental separation can have very different material consequences depending on the marital status of the parents. Alimony is a legal obligation after marriage dissolution in most countries that is paid to a former partner. However, the same legal obligations do not always apply to unmarried couples.

56. Of the countries that allow registered partnerships, Greece and the Netherlands grant registered couples the same partner alimony rights as married couples, while Belgium and France do not. Out of the eighteen countries covered in Figure 11, only Slovenia explicitly extends the same alimony rules to informal cohabitants. Other countries acknowledge partner alimony rights in the presence of children (Germany, Hungary and Ireland) or at the discretion of the courts on a case-by-case basis (Belgium, Finland and France).

\footnotetext{
${ }^{2}$ In Portugal this right is only valid for a period equal to the length of cohabitation, so it is not technically an inheritance.
} 
Figure 11. In case partners split up, do statutory rules on alimony to former partners apply?

\begin{tabular}{|c|c|c|c|}
\hline \multicolumn{2}{|c|}{ Registered partnership } & \multicolumn{2}{|c|}{ Informal cohabitation } \\
\hline $\begin{array}{l}\text { The same } \\
\text { rights as } \\
\text { married } \\
\text { couples }\end{array}$ & $\begin{array}{c}\text { Not the same } \\
\text { rights as } \\
\text { married } \\
\text { couples }\end{array}$ & $\begin{array}{l}\text { The same } \\
\text { rights as } \\
\text { married } \\
\text { couples }\end{array}$ & $\begin{array}{c}\text { Not the same } \\
\text { rights as } \\
\text { married } \\
\text { couples }\end{array}$ \\
\hline Austria & Belgium & Slovenia & Belgium \\
\hline Greece & France & & Finland \\
\hline \multirow{2}{*}{\multicolumn{2}{|c|}{ Netherlands }} & & France \\
\hline & & & Germany \\
\hline \multirow{2}{*}{\multicolumn{2}{|c|}{$\begin{array}{l}\text { Countries where registered partnership } \\
\text { for opposite sex couples do not exist }\end{array}$}} & & Hungary \\
\hline & & & Ireland \\
\hline Czech Republic & Ireland & \multirow{2}{*}{\multicolumn{2}{|c|}{ No rights to partner alimony }} \\
\hline Finland & Italy & & \\
\hline Germany & Norway & Austria & Norway \\
\hline Hungary & Poland & Czech Republic & Poland \\
\hline Portugal & Slovenia & Greece & Portugal \\
\hline Iceland & Sweden & Italy & Sweden \\
\hline \multirow[t]{2}{*}{ United Kingdom } & & Iceland & United Kingdom \\
\hline & & Netherlands & \\
\hline
\end{tabular}

Note: 1) Data from 2019 for Austria, 2016 for Ireland, Italy, and the United Kingdom. Data from 2015 for Belgium, the Czech Republic, Finland, France, Germany, Greece, Hungary, Iceland, Ireland, the Netherlands, Norway, Poland, Portugal, Slovenia and Sweden. 2) The United Kingdom refers to three jurisdictions (England and Wales, Northern Ireland, and Scotland) 3) Property at dissolution refers to question: "In case the partners split up, do statutory rules consider as joint property any possessions acquired by either of them after they started this type of relationship?" 4) Eligibility for the right or partial right depends at least partly on the presence of children. 5) In Portugal, the surviving partner is entitled to alimony from the inheritance of the deceased, which will cease in case of new marriage, new cohabitation or undignified behaviour.

Source: Author categorisation based on the information given by the LawsAndFamilies database, https://www.lawsandfamilies.eu/.

57. The division of property acquired before separation also depends on partnership status. Many countries have a system of joint marital property, with exceptions for gifts or inheritance, while in other countries, property is acquired individually. In most cases, a couple can have a pre-nuptial contract and change the default marital property regime. Of those that allow registered partnerships, states extend the same marital property regime, except in Belgium and France, which allow the division of "common" property at dissolution only if it can be proved it was joint. Of countries with a separate marital property regime or those that give a choice, only Austria and Italy does not give marital couples other rights related to the division of property, such as a chance to opt into a common property regime (Germany), rights to the family home (Portugal), apply a general rule of division by half (Iceland), or allow claims to the other's property at the discretion of the courts (Greece, Ireland, Sweden and the United Kingdom). Otherwise, where there is a regime of joint marital property, only Slovenia fully extends the same marital rights to property at dissolution to cohabiters. Most allow for partial rights to cohabiters by allowing claims of joint property, either at the agreement of both cohabiters or at the court's discretion (Finland, France, Hungary, the Netherlands, and Norway). Belgium, the Czech Republic, and Poland do not make explicit any such provisions. 
58. This large heterogeneity reflects the diversity of the historical paths followed by countries to adapt their system to the vagaries of family life and new forms of marital life. However, from the child's point of view, the risk is that they may find themselves in the midst of a conflict that can lead to an unequal distribution of property between parents and in turn, their own material well-being, depending on the type of custody. Countries can reduce this risk by making joint property available to unmarried couples who acquire common property and treating the division of property in the event of separation in a similar way regardless of marital status.

\subsubsection{Better acknowledge the presence of two custodial parents}

59. Sharing custody of children is increasingly common in many countries. Often, this an effective way to maintain a father's involvement in their children's education and care. Sharing physical custody of children reduces the amount of child support paid by one parent to another, compared to the case with one custodial parent. However, it also creates additional costs since each parent should have a home with enough space, furniture, etc. to accommodate their children. Increased costs and lower transfers between parents raise the risk of poverty faced by children with two "sole" parents - and especially by female headed sole parent households (Bonnet, Garbinti and Solaz, 2016 [38]; Ha, Cancian and Meyer,

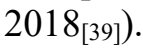

60. There are large differences in how countries take into account shared custody arrangements when calculating alimony obligations. There can be almost no guidance, as in Germany or Sweden, or detailed recommendations, as in Finland or Australia. For instance in Finland, ministries have detailed recommendations: A parent receives a smaller amount of child support if the other parent cares for the child for at least seven nights per month. Other subsequent cut-off points are when the time share reaches 10 and 13 nights per months, after which child maintenance payment can be cancelled. In Australia, child custody is shared if each parent takes care of the child at least $35 \%$ of the time, with the amount of child support due decreasing as the time shared increases. In Sweden, there is no consideration of different thresholds, and no child support is required from either parent when a child spends an equal amount of time in both households (Hakovirta and Rantalaiho, 2011 $\left.1_{[40]}\right)$. Conversely, in Canada, France, and the United Kingdom, fathers are expected to continue to contribute financially to equalize the lower income of mothers, even when also participating in childcare.

61. Accounting for custodial arrangements and parental preferences is a good general guideline, yet it does not guard against parents acting according to their own interests rather than their children's. For instance, a parent who pays (gets) child support may push for (resist) an extra night per week for the child to stay (leave) in his/her dwelling, simply to reduce (maintain) the child support payment due. A way to limit this risk is to put boundaries on the reduction of child support payments that are associated with a change in the custody arrangements (Claessens and Mortelmans, 2018). For instance, in Canada, there is only one cut-off to reduce the child support paid by one parent to the other when a child resides with each for at least 40 percent of the time.

62. The issues become even more complex when one of the parents re-partner. While new partners may have no financial obligations towards children for whom the parent pays or receives child support, their financial status does influence the household income, either as an expense or a resource. If the parent due child support has a financially dependent partner, their capacity to pay child support is reduced. Child support schemes can either ignore this financial burden or calculate child support after considering these expenses. 
Conversely, if partners who are living together are expected to support each other financially, a new partner may increase available household income. For a paying parent, this may increase their capacity to pay and possibly affect the child support amount due.

63. The issue of paying an equitable amount of child alimony is further complicated if the parent paying a child alimony has a child with the new partner. Child support schemes may ignore financial obligations towards a new child, judging that children from a previous relationship should not be deprived of parental resources. However, a new child has equal rights to these resources and there are various ways to acknowledge this, although no system is ideal (Meyer, Skinner and Davidson, 2011 $1_{[41]}$ ).

64. When parents only have children in common, countries do not require an equal amount for each child even though they are full siblings. Obligations to second born children are always lower, justified in part by economies of scale. In this simple case, the paying parent has a more affordable alimony order due, and it is possible for the resident parent to allocate the child support so that the two children have equal standards of living, allowing a balance between equality and affordability, even if not required by the child support system.

65. However, this type of equality is not possible in complex family situations, where children live in different households and therefore cannot share household resources. In some countries, as for instance in Belgium and France, the treatment of cases where resident and non-resident children coexist is subject to judicial discretion (Meyer, Skinner and Davidson, 2011 $1_{[41]}$ ). Some other countries lean instead towards protecting the first nonresident child's standard of living. However, excessive obligations to maintain the level of support for the older child may conflict with both the financial and time investment that fathers have towards their youngest child (Tach et al., 2014 ${ }_{[42]}$ ). Evidence also suggests that child support enforcement policies can increase the debt burden of low-income fathers, with the unintended consequence of reducing their employment intensity, earnings, and the actual level of child support payment (Cancian, Heinrich and Chung, $2013_{[43]}$ ).

66. Other countries employ formula or guidelines to reduce a child support order to a non-resident child when a non-resident parent has a new resident child. Among these countries, Denmark, the United Kingdom and Canada (Ontario) apply a certain principle of equality by reducing the order to the older non-resident child. In this way, the obligation is more affordable for the non-resident parent, but it also results in a decline of the nonresident child's order without any protection for their standard of living, which could be unfair to the first child. In Finland, Sweden and the Netherlands, expenses and income of a new partner are taken into account and the child support order can be reduced if the household resources of the "paying" parent fall or if the household resources of the custodial parent increase.

\subsubsection{Strengthen obligations and support to the non-custodial parent}

67. Some children live with their biological parent who may have children from a previous union, so the parent is bound to pay child support. Alternatively, children may live with a step-parent who may also have biological children living in other households. In these situations, the material well-being of children will crucially depend on the ability of parents to support all children for whom they are responsible, regardless of where they live. 
68. Child support payments often make up for an important source of the income of single parent families: they represent on average $14 \%$ of the available income of the receiving household in the OECD (OECD, 2011 $1_{[36]}$ ) (Beaumont, Mason and Schulze, $2014_{[37]}$. However, this share is even higher if the full amount of child support due was paid. In the United States, child support payments account for about $10 \%$ of the mean personal income of households receiving the payment on average in 2015. It represents $16 \%$ of household income for those who received the full support they were supposed to receive (Grall, 2018 $\left.{ }_{[44]}\right)$.

69. Child support is even more important for lower income parents. For example, among American custodial parents below the poverty line and who receive full payments, the mean annual child support received in 2015 represented 58 percent of their mean personal income. Child support payments are so key to prevent poverty in families with separated parents.

70. Non-payment (or delayed payment) of child support is not uncommon. In France, between 30 and $40 \%$ of alimony payments due to families with children are unpaid or partially paid, and re-partnering and/or break-up with new partners are frequently the cause of the (temporary) suspension of child support payments (Favrat and Fernandez, 2016 ${ }_{[45]}$ ). In the United States, around $43 \%$ of custodial parents receive the full amount due to them and about $30 \%$ receive nothing at all (Grall, 2018 $\left.{ }_{[44]}\right)$. On average, custodial parents with a child support order receive roughly $60 \%$ of their order amount.

71. Repercussions for the non-payment of child maintenance by the non-custodial parent can range from enforced payment, salary deductions, seizure of assets and bank accounts, and, in some countries, imprisonment. Child support can be guaranteed in some countries by the state (in Austria, Estonia, Finland, Germany, Hungary, Italy and Sweden); by local authorities (in the Czech Republic and Finland); by special funds (in Latvia, Lithuania, Luxembourg, Poland and Portugal); or by a special administrative agency (in Denmark, France, the Netherlands and the United Kingdom). Several countries, including Australia, New Zealand, the United Kingdom and more recently France, have strengthened their systems to assist parents pursuing their claims and to help them take the appropriate administrative and/or legal steps.

72. While it is necessary to strengthen the enforcement of child maintenance obligations, helping non-custodial parents be self-sufficient is key to enabling them to fulfil their obligations regarding child support payments in the long-run (Berger, 2017 ${ }_{[46]}$ ). Noncustodial parents often lack stable employment, may work for low wages, or may have a new family to support which hampers their ability to comply with child support payments (Ha, Cancian and Meyer, 2018[39]). Providing vulnerable non-custodial parents with the employment and/or social supports they need to be self-sufficient reduces the risk of "nonpayment". The provision of such "self-sufficiency" supports should be conditional on the payment of child support. Another option to strengthen support to non-custodial parents is to include non-resident children in the calculation of means-tested benefits and/or to childrelated tax allowances (Berger, 2017 [46] $)$. Evidence suggests that arrangements to facilitate the payment of child support arrears work as incentives to enter and remain in employment, enhancing the ability to comply with child alimony payment obligations (Heinrich, Burkhardt and Shager, 2011 $\left.{ }_{[47]}\right)$. 


\section{Conclusion}

73. The diversification of family living arrangements increased the number of children living with parents who cohabit informally and whose rights to social protection differ from those of married couples. Ignoring this trend in informal cohabitation can lead to exposing the children of these couples to greater economic risks compared to the children of their married counterparts.

74. Shared custody of children after separation is more frequent and the diversification of family living arrangements after parental separation requires introducing greater flexibility in child maintenance systems. Living arrangement following separation and possible subsequent family reformation creates multiple obligations that some parents are unable to fulfil due to their fragile economic situation. Supporting parents economically can be key to help them fulfil their family obligations. To this aim, self-sufficiency can also be enhanced by ensuring that the child-related costs of children born by the non-custodial parents are taken into account when setting up eligibility criteria for welfare benefits and that changes in child support payments do not lead to drastic reductions in social assistance payment (Skinner et al., 2017 ${ }_{[48]}$ ). Social protection in some countries has taken a step in this direction. For instance, in France, following a decision by the Conseil d'Etat in 2017, each parent can now receive a housing allowance in cases of shared custody. The amount granted is calculated based on the period during which each parent has the child in his or her own home during the year.

75. However, changes in family behaviour pose serious challenges to the child support enforcement program, and it is increasingly difficult to determine appropriate child support orders in a context where parents are not necessarily married, may have children with multiple partners and a preference for various family living arrangements after family dissolution. Historically, mothers were assumed to be as the only custodial parent, and the noncustodial parents (generally fathers) were assumed to have all their children with the same custodial parent. Yet, in the context where shared custody and multi-partner fertility both become more frequent, it is difficult to determine child support orders that are simultaneously "fair" from the perspective of custodial parents, noncustodial parents and children in different households (Meyer, Skinner and Davidson, 2011 [41]; Berger and Carlson, 2020 $[4])$. 
76. Moreover, regardless of opinions about the ideal family living arrangement, treating all children equally requires that child support benefits and other social protections are accessible regardless of the civil status of their parent's relationship and that children are given the support that reflects their family living arrangements. The elimination of differences in social protection rights based on civil status of parents is crucial to guarantee children have equal rights, yet it faces various hurdles. A first hurdle relates to the willingness of countries to expand the rights and protections granted to marriage to other forms of unions. Some countries may prefer to preserve the privileged status of marriage in order to encourage couples to marry, especially if they have children. In this case, the risk is that children of unmarried parents will be treated unequally, in terms of their access to certain rights. Other countries may instead choose to extend the same rights and protections as marriage to children whose parents live together. The concern in this case is this could encourage couples to cohabit without strong reciprocal obligations and so may contribute to union instability, particularly among the most vulnerable population groups. Although in some countries (such as the United States), evidence suggests that partners with low levels of education are more likely to cohabit than to marry, this is not always the case, especially in European countries (such as Belgium, France, Italy and the Netherlands). Overall, the characteristics of couples who cohabitate seems to be more dependent on the institutional context of countries they live in rather than any one characteristic, such as individual education levels.

77. The fluidity between different family living arrangements requires rapid adjustments of family support to changing family and employment situations, or housing conditions affecting families and children. The increased use of digital technology, teleprocedures and the electronic transmission of information to benefit recipients can help track changes in earnings and family living arrangements, which in the end, may facilitate the management of complex cases. However, the experience with making incomedependent, child-related payments in different OECD countries demontrastes the limits to which social protection systems can accurately respond to changing income and household arrangements (OECD, 2019[49]).

78. The growing diversity and fluidity of family life will further challenge tax/benefit systems to be more responsive to changes in children's living arrangements. This requires better information systems and transparent benefit criteria to help social policy treat all children equally and deliver supports in line with their living conditions.

79. Finally, the discussion in this paper has focused only on some aspects of the diversification of family living arrangements, but other changes in family life will impact on children's well-being if family support policies does not adapt to these changes. This is particularly the case for families with same-sex parents, or with parents of different nationalities, where children born into such families do not always have the same social protection as children from traditional families. A study of the rights and protections of children growing up in such families is needed to better cover the diversity of families. 


\section{References}

Abela, A. and J. Walker (2013), Contemporary issues in family studies : global perspectives on partnerships, parenting and support in a changing world.

Allègre, G., H. Périvier and M. Pucci (2019), Imposition des couples en France et statut marital : simulation de trois réformes du quotient conjugal, OFCE Sciences Po, http://www.ofce.sciences-po.fr/pdf/dtravail/OFCEWP2019-05.pdf (accessed on 27 March 2019).

Amato, P. and L. Boyd (2013), "Children and Divorce in World Perspective", in Contemporary Issues in Family Studies, John Wiley \& Sons, Oxford, http://dx.doi.org/10.1002/9781118320990.ch16.

Beaumont, K., P. Mason and E. Schulze (2014), Child maintenance systems in EU Member States from a gender perspective, European Parliament, http://www.europarl.europa.eu/RegData/etudes/note/join/2014/474407/IPOLFEMM_NT(2014)474407_EN.pdf (accessed on 11 April 2018).

Berger, L. (2017), A new Safety Net for 21st-Century Families, http://inequality.stanford.edu/sites/default/files/Pathways_Spring2017_Family-Safety-Net.pdf (accessed on 12 November 2018).

Berger, L. (2016), Family complexity and fluidity, child and family wellbeing and public policyn Wisconsin future of the family commission, https://dcf.wisconsin.gov/files/fotf/pdf/bergerpresentation.pdf.

Berger, L. and M. Carlson (2020), "Family Policy and Complex Contemporary Families: A Decade in Review and Implications for the Next Decade of Research and Policy Practice", Journal of Marriage and Family, Vol. 82/1, pp. 478-507, http://dx.doi.org/10.1111/jomf.12650.

Bernardi, F. et al. (n.d.), State-of-the-art report Effects of family forms and dynamics on children's well-being and life chances: literature review Changing families and sustainable societies: Policy contexts and diversity over the life course and across generations 4 (2013) Effects of family forms and dynamics on children's well-being and life chances: literature review, http://www.familiesandsocieties.eu/wpcontent/uploads/2014/12/WP04BernardiEtal2013.pdf (accessed on 12 November 2018).

Bernardi, L. and D. Mortelmans (eds.) (2018), Lone Parenthood in the Life Course, Springer International Publishing, Cham, http://dx.doi.org/10.1007/978-3-319-63295-7.

Besharov, D. and N. Gilbert (2015), "Marriage Penalties in the modern social Welfare State", $R$ STREET POLICY STUDY, https://www.http://www.welfareacademy.org/pubs/family/Marriage_Penalties_in_the_Moder n Social-Welfare State.pdf (accessed on 12 November 2018). 
Bonnet, C., B. Garbinti and A. Solaz (2016), "Gender Inequality after Divorce: The Flip Side of Marital Specialization Evidence from a French Administrative Database - Documents de travail - G2016/03 | Insee", No. G2016/03, INSEE, https://www.insee.fr/en/statistiques/2022141 (accessed on 27 March 2019).

Bzostek, S. and L. Berger (2017), "Family Structure Experiences and Child Socioemotional Development During the First Nine Years of Life: Examining Heterogeneity by Family Structure at Birth", Demography, Vol. 54, pp. 513-540, http://dx.doi.org/10.1007/s13524017-0563-5.

Cancian, M., C. Heinrich and Y. Chung (2013), "Discouraging Disadvantaged Fathers' Employment: An Unintended Consequence of Policies Designed to Support Families", Journal of Policy Analysis and Management, Vol. 32/4, pp. 758-784, http://dx.doi.org/10.1002/pam.21707.

Cancian, M., D. Meyer and S. Cook (2011), "The Evolution of Family Complexity from the Perspective of Nonmarital Children", Demography, Vol. 48, pp. 957-982, http://dx.doi.org/10.2307/41237819.

Claessens, E. and D. Mortelmans (2018), "Challenges for child support schemes: Accounting for shared care and complex families", Journal of European Social Policy, Vol. 28/3, pp. 211223, http://dx.doi.org/10.1177/0958928717753592.

Doepke, M. and F. Zilibotti (2019), Love, money \&amp; parenting : how economics explains the way we raise our kids, https://press.princeton.edu/titles/13326.html (accessed on 15 May 2019).

Eickmeyer, K., W. Manning and S. Brown (2019), "What's Mine Is Ours? Income Pooling in American Families", Journal of Marriage and Family, p. jomf.12565, http://dx.doi.org/10.1111/jomf.12565.

Favrat, A. and V. Fernandez (2016), Trajectoires de perception de pensions alimentaires Eléments tirés du panel d'allocataires des Caf, http://Présentation au Haut Conseil de la Famille.

Grall, T. (2018), Custodial Mothers and Fathers and Their Child Support: 2015 Current Population Reports, http://www.census.gov/topics/families (accessed on 12 November 2018).

Hakovirta, M. and M. Rantalaiho (2011), "Family Policy and Shared Parenting in Nordic Countries", European Journal of Social Security, Vol. 13/2, pp. 247-266, http://dx.doi.org/10.1177/138826271101300203.

Haut Conseil de la Famille (2014), Les ruptures familiales: Etat des lieux et propositions, http://www.hcfea.fr/IMG/pdf/2014 04_LES RUPTURES_FAMILIALES.pdf (accessed on 11 April 2018).

Haut Conseil de la Famille (2011), Architecture de la politique familiale: éléments de problématique, Haut Conseil de la Famille, http://www.hcfea.fr/IMG/pdf/Architecture_Problematique-2.pdf. 
Ha, Y., M. Cancian and D. Meyer (2018), "Child Support and Income Inequality", Poverty \& Public Policy, Vol. 10/2, pp. 147-158, http://dx.doi.org/10.1002/pop4.215.

Heinrich, C., B. Burkhardt and H. Shager (2011), "Reducing child support debt and its consequences: Can forgiveness benefit all?", Journal of Policy Analysis and Management, Vol. 30/4, pp. 755-774, http://dx.doi.org/10.1002/pam.20599.

Henman, P. et al. (2007), Improving the lives of Australians Costs of children: research commissioned by the Ministerial Taskforce on Child Support, http://www.ag.gov.au/cca. (accessed on 12 November 2018).

Henman, P. et al. (2007), Improving the lives of Australians Costs of children: research commissioned by the Ministerial Taskforce on Child Support, http://www.ag.gov.au/cca. (accessed on 27 March 2019).

Hiekel, N., A. Liefbroer and A. Poortman (2014), "Income pooling strategies among cohabiting and married couples: A comparative perspective", DEMOGRAPHIC RESEARCH, Vol. 30, http://dx.doi.org/10.4054/DemRes.2014.30.55.

Iacovou, M. and A. Skew (2011), "Household composition across the new Europe: Where do the new Member States fit in?", Demographic Research, Vol. 25/14, pp. 465-490, http://dx.doi.org/10.4054/DemRes.2011.25.14.

Jelloul, B. and P. Cusset (2015), Comment partager équitablement le coût des enfants après la séparation?, http://www.strategie.gouv.fr (accessed on 12 November 2018).

Lopoo, L. and K. Raissian (2014), "U.S. Social Policy and Family Complexity", The ANNALS of the American Academy of Political and Social Science, Vol. 654/1, pp. 213-230, http://dx.doi.org/10.1177/0002716214530372.

Maag, E. and G. Acs (2015), The Financial Consequences of Marriage for Cohabiting Couples with Children, https://www.urban.org/sites/default/files/publication/65776/2000366-TheFinancial-Consequences-of-Marriage-for-Cohabiting-Couples-with-Children\%20.pdf (accessed on 12 November 2018).

Martin, H. and H. Périvier (2018), “Les échelles d'équivalence à l'épreuve des nouvelles configurations familiales", Revue économique, Vol. Prépublication/0, p. 70, http://dx.doi.org/10.3917/reco.pr2.0114.

McLanahan, S. and W. Jacobsen (2015), "Diverging Destinies Revisited", Springer, Cham, http://dx.doi.org/10.1007/978-3-319-08308-7_1.

Meyer, D., C. Skinner and J. Davidson (2011), "Complex families and equality in child support obligations: A comparative policy analysis", Children and Youth Services Review, Vol. 33/10, pp. 1804-1812, http://dx.doi.org/10.1016/J.CHILDYOUTH.2011.05.011.

Millar, J. and Whiteford P. (2017), Timing it wrong: benefits, income tests, overpayments and debts | Inside Story, https://insidestory.org.au/timing-it-wrong-benefits-income-testsoverpayments-and-debts/ (accessed on 12 December 2019). 
Mortelmans, D. et al. (2015), Analysis of determinants and prevalence of LAT Changing families and sustainable societies: Policy contexts and diversity over the life course and across generations Analysis of determinants and prevalence of $L A T$, http://www.familiesandsocieties.eu/wp-content/uploads/2015/01/WP25MortelmansEtAl.pdf (accessed on 13 November 2018).

OECD (2019), "Left on your own? Social protection when labour markets are in flux", in OECD Employment Outlook 2019: The Future of Work, OECD Publishing, Paris, https://dx.doi.org/10.1787/bfb2fb55-en.

OECD (2011), Doing Better for Families, OECD Publishing, Paris, http://dx.doi.org/10.1787/9789264098732-en.

Pailhé, A. et al. (2014), State-of-the-art report Changes in the life course Changing families and sustainable societies: Policy contexts and diversity over the life course and across generations, http://www.familiesandsocieties.eu/wpcontent/uploads/2014/12/WP6PailheMortelmansEtal2014.pdf (accessed on 12 November 2018).

Paris Seminar on Economic Demography, 5. (ed.) (2012), Consumption units and equivalence scales in a mult-residence framework, http://, http://psed.site.ined.fr/fichier/rte/46/PSED/Toulemon_PSED_5-6-2012.pdf.

Perelli-Harris, B. et al. (2014), "Towards a new understanding of cohabitation", Demographic Research, Vol. 31, pp. 1043-1078, http://dx.doi.org/10.4054/demres.2014.31.34.

Perelli-Harris, B. et al. (2014), "Towards a new understanding of cohabitation", Demographic Research, Vol. 31, pp. 1043-1078, http://dx.doi.org/10.4054/demres.2014.31.34.

Perelli-Harris, B. et al. (2014), "Towards a new understanding of cohabitation", Demographic Research, Vol. 31, pp. 1043-1078, http://dx.doi.org/10.4054/demres.2014.31.34.

Perelli-Harris, B. et al. (2014), "Towards a new understanding of cohabitation", Demographic Research, Vol. 31, pp. 1043-1078, http://dx.doi.org/10.4054/demres.2014.31.34.

Perelli-Harris, B. and N. Gassen (2012), "How Similar Are Cohabitation and Marriage? Legal Approaches to Cohabitation across Western Europe", Population and Development Review, Vol. 38/3, pp. 435-467, http://dx.doi.org/10.1111/j.1728-4457.2012.00511.x.

Perelli-Harris, B. et al. (2012), "Changes in union status during the transition to parenthood in eleven European countries, 1970s to early 2000s", Population Studies, Vol. 66/2, pp. 167182, http://dx.doi.org/10.1080/00324728.2012.673004.

Perelli-Harris, B. et al. (2012), "Changes in union status during the transition to parenthood in eleven European countries, 1970s to early 2000s", Population Studies, Vol. 66/2, pp. 167182, http://dx.doi.org/10.1080/00324728.2012.673004.

Perelli-Harris, B. et al. (2012), "Changes in union status during the transition to parenthood in eleven European countries, 1970s to early 2000s", Population Studies, Vol. 66/2, pp. 167182, http://dx.doi.org/10.1080/00324728.2012.673004. 
Perelli-Harris, B. et al. (2012), "Changes in union status during the transition to parenthood in eleven European countries, 1970s to early 2000s", Population Studies, Vol. 66/2, pp. 167182, http://dx.doi.org/10.1080/00324728.2012.673004.

Perelli-Harris, B. and M. Lyons-Amos (2016), "Partnership Patterns in the United States and across Europe: The Role of Education and Country Context", Social Forces, Vol. 95/1, pp. 251-282, http://dx.doi.org/10.1093/sf/sow054.

Population Association of America (ed.) (2013), Maternal Re-Partnering and Child Development during the First Nine Years of Life, http://http ://paa2013.princeton.edu/papers/130592.

Pryor, J. (2013), "Marriage and Divorce in the Western World", in Contemporary Issues in Family Studies, John Wiley \& Sons, Oxford, http://dx.doi.org/10.1002/9781118320990.ch4.

Régnier-Loilier, A., E. Beaujouan and C. Villeneuve-Gokalp (2009), "Neither single, nor in a couple: A study of living apart together in France", Demographic Research, Vol. 21/4, pp. 75-108, http://dx.doi.org/10.4054/DemRes.2009.21.4.

Sánchez Gassen, N. and B. Perelli-Harris (2015), "The increase in cohabitation and the role of union status in family policies: A comparison of 12 European countries", Journal of European Social Policy, Vol. 25/4, pp. 431-449, http://dx.doi.org/10.1177/0958928715594561.

Seltzer, J. (2019), "Family Change and Changing Family Demography", Demography, Vol. 56/2, pp. 405-426, http://dx.doi.org/10.1007/s13524-019-00766-6.

Skinner, C. et al. (2017), "Child Maintenance and Social Security Interactions: the Poverty Reduction Effects in Model Lone Parent Families across Four Countries", Journal of Social Policy, Vol. 46/03, pp. 495-516, http://dx.doi.org/10.1017/S0047279416000763.

Sorrentino, C. (1990), "The changing family in international persepctive", Monthly Labor Review, https://www.bls.gov/mfp/mprsor90.pdf (accessed on 12 November 2018).

Tach, L. et al. (2014), "The Family-Go-Round", The ANNALS of the American Academy of Political and Social Science, Vol. 654/1, pp. 169-184, http://dx.doi.org/10.1177/0002716214528655.

Thévenon, O. (2018), "Child Poverty: Trends, determinants and policies to tackle it", OECD Social, Employment and migrations Working papers, OECD Publishing.

Thévenon, O. (2011), "Why reform preschool daycare in France? A comparison with other OECD countries", Revue d'Economie Politique, Vol. 121/5.

Toulemon, L. (2016), Children with multiple residence: how many, in which families?.

Toulemon, L. (2012), Consumption units and equivalence scales in a multi-residence framework, Paris Seminar on Economic Demography, Paris. 
UNECE (United Nations Economic Commission for Europe (2011), Measurement of emerging forms of families and households, United Nations, http://www.unece.org/fileadmin/DAM/stats/publications/Families and_Households FINAL. pdf (accessed on 12 November 2018).

UNECE, (. (2011), Measurement of emerging forms of families and households, United Nations, New York and Geneva, http://www.unece.org/fileadmin/DAM/stats/publications/Families_and_Households_FINAL. pdf (accessed on 12 November 2018).

Vanassche, S. (2013), Stepfamily configurations and trajectories following parental divorce: A quantitative study on stepfamily situations, stepfamily relationships and the well-being of children, KV Leuven, https://lirias.kuleuven.be/handle/123456789/414518 (accessed on 12 November 2018).

Wu, H. (2017), Trends in Births to Single and Cohabiting Mothers, 1980-2014, National Center for Family and Marriage Research Family Profiles, https://www.bgsu.edu/ncfmr/resources/data/family-profiles/wu-trends-births-singlecohabiting-mothers-fp-17-04.html (accessed on 27 March 2019). 